\title{
Systemic therapy for metastatic pancreatic adenocarcinoma
}

\author{
Ben Lawrence and Michael Findlay
}

\begin{abstract}
Systemic treatment of metastatic pancreatic adenocarcinoma achieves only modest benefits, with evidence indicating a survival advantage with 5 -fluorouracil (5-FU) over best supportive care alone, and further advantage of single-agent gemcitabine over 5 -FU. There are very few regimens better than single-agent gemcitabine despite multiple trials of cytotoxic and targeted agents. The addition of a platinum agent has improved response rate but not survival. The addition of erlotinib has improved survival but only by a small margin. The use of gemcitabine in multidrug regimens containing one or more of: a platinum agent; fluoropyrimidine; anthracycline; and taxane has demonstrated advantages in response rate, progression-free survival and, in one randomized study, overall survival. After gemcitabine failure, second-line therapy with oxaliplatin and 5-FU provides a further survival advantage. Further advances depend upon the current and future clinical trials investigating enhanced delivery of current agents, new agents and novel modalities, improved supportive care, and treatment more tailored to the individual patient and tumour.
\end{abstract}

Keywords: adenocarcinoma, antineoplastic agents, chemotherapy, metastatic therapeutics, pancreas, pancreatic neoplasms

\section{Background}

Pancreatic adenocarcinoma (PAC) is unresectable at diagnosis in $80 \%$ of patients, and if not already metastatic will usually become so. Conventional measures to modify the natural history of this disseminated disease are only modestly helpful with small survival advances in the palliative setting. With current treatments, $41 \%$ of patients with local or regional disease survive to 1 year, but only $13 \%$ of patients with metastatic disease achieve this milestone [SEER, 1996-2004]. The aim of this review is to provide the clinician with an up-to-date summary of current evidence for the treatment of metastatic PAC and provide insights into future research directions.

\section{Method}

A systematic search of published trials and recent abstracts was conducted using Medline, Embase, The Cochrane Database of Systematic Reviews, and the abstracts lists from the past 4 years of the American Society of Clinical Oncology (ASCO) and ASCO Gastrointestinal congress, and the European Society of Medical Oncology (ESMO) congress. The Medline search (including Medline in process) was conducted using the strategy [*pancreatic neoplasms/dt AND *adenocarcinoma /dt AND metast\$.mp NOT (radio\$ or adjuv\$).mp] LIMIT TO [(clinical trial, all OR clinical trial, phase I OR clinical trial phase II OR clinical trial phase III, OR clinical trial, phase IV OR clinical trial OR controlled clinical trial OR meta analysis OR randomized controlled trial)]. Embase was searched using the strategy [(*Pancreas Adenocarcinoma/dt OR metastatic pancreatic adenocarcinoma.mp) AND exp evidence based medicine]. The Cochrane Database of Systematic Reviews was searched for any reviews regarding advanced or metastatic pancreatic cancer. Trials with at least some patients with metastatic PAC were included. Studies were excluded if they were phase I only, involved radiotherapy, if doses could not be obtained from an English language abstract or article, and if groups included both previously treated and nontreated participants.

\section{Chemotherapy in addition to best supportive care}

Some clinicians remain uncertain whether chemotherapy offers added benefit over best
Ther Adv Med Oncol

(2010) 2(2) 85-106

DOI: $10.1177 /$

1758834009357188

(C) The Author(s), 2010. Reprints and permissions:

http://www.sagepub.co.uk/ journalsPermissions.nav
Correspondence to: Ben Lawrence Department of Medical Oncology, Regional Cancer and Blood Service, Auckland City Hospital, Private Bag 92024, Auckland, New Zealand benjaminladadhb.govt.nz Michael Findlay Department of Medical Oncology, School of Medical Sciences, Faculty of Medical and Health Sciences, University of Auckland, New Zealand 
supportive care (BSC) alone for patients with metastatic PAC. Interpreting trial data is complicated by a variety of factors such as a wide variation in response rate and survival between phase II trials; subsequent phase III trials are usually negative; the participant groups are a mixture of locally advanced and metastatic disease; the effect sizes are usually small; multiple regimens have been tested; study size is sometimes too small to detect differences. Registry data from patients with metastatic PAC in Veterans Affairs Hospitals between 1995 and 2005 showed that patients who received chemotherapy lived longer than untreated patients, at 5.3 versus 1.5 months median overall survival (OS), respectively [Mekan et al. 2007]. These data are retrospective and might only reflect the performance status of patients at the time of consideration for chemotherapy.

A Cochrane review compared fluorouracil (5-FU)-based chemotherapy with BSC in seven randomized controlled trials (RCTs) [Yip et al. 2006]. The meta-analysis showed that 5-FU-based regimens reduced 12-month mortality when compared to BSC [odds ratio (OR) 0.37 , confidence interval (CI) $0.25-0.57$, $p<0.00001]$. There were some limitations in generalizability. Firstly, two of the trials trended towards supporting BSC over chemotherapy, and the study that most favoured chemotherapy had not required a histological diagnosis. Secondly, although five of the studies attempted to measure some aspect of quality of life, only two showed any improvement with chemotherapy.

Three further randomized phase II trials have compared chemotherapy to best supportive care. No survival benefit was obtained from gemcitabine (after biliary stenting) [Xinopoulos et al. 2008], a combination of cisplatin and 5-FU [Huguier et al. 2001], or the hormonal agent, flutamide [Negi et al. 2006].

\section{Single-agent chemotherapy}

\section{Fluoropyrimidines}

The modest activity of 5-FU-containing regimens in the Cochrane review has some support from nonrandomized phase II studies using $5-\mathrm{FU}$ as a single agent. Both bolus and infusional 5-FU regimens have achieved radiological response rates up to $15 \%$ and median OS up to 5 months [Van Rijswijk et al. 2004; Di Costanzo et al. 1996; Weinerman and MacCormick, 1994]. Two oral
5-FU pro-drugs have shown similar results. Capecitabine alone $\left(1250 \mathrm{mg} / \mathrm{m}^{2}\right.$ bd, d1-14 q3w) achieved a $10 \%$ response rate, but a $24 \%$ clinical benefit response rate [Cartwright et al. 2002]. S1 $\left(30 \mathrm{mg} / \mathrm{m}^{2} \mathrm{bd}, \mathrm{d} 1-14 \mathrm{q} 3 \mathrm{w}\right)$ showed a $21 \%$ response rate and median OS of 5.6 months in one trial [Ueno et al. 2005], but only 9\% response rate in another [Strumberg et al. 2009]. Fluorodeoxyuridine [Ardalan and Lima, 2004] and the oral agents dFUR [Di Bartolomeo et al. 1996], and uracil-tegafur [Ueno et al. 2002] were not effective.

\section{Platinum drugs}

Platinum drugs might have some single-agent activity in metastatic PAC. In a nonrandomized phase II trial, cisplatin alone $\left(100 \mathrm{mg} / \mathrm{m}^{2} \mathrm{q} 4 \mathrm{w}\right)$ achieved a response rate of $21 \%$ [Wils et al. 1993], but platinum drugs have not been tested as single agents in a RCT.

\section{Other single agents}

Many other cytotoxic and biological agents have been tested in phase II trials and have shown no single-agent activity. These include mitoxantrone [Taylor et al. 1990], Mitomycin Natural Killer [Tuinmann et al. 2008], paclitaxel [Gebbia and Gebbia, 1996], topotecan [Stevenson et al. 1998], fludarabine [Kilton et al. 1992], glufosfamide [Briasoulis et al. 2003], dihydroxyanthracenedione [Asbury et al. 1994; Bukowski et al. 1993], aziridinylbenzoquinone [Bukowski et al. 1993], lithium gamolenate [Johnson et al. 2001], etoposide [Asbury et al. 1994], aclacinomycin, spirogermanium [Asbury et al. 1994], maytansine, chlorozotocin [GITSG, 1985], octreotide [Burch et al. 2000], lantreotide [Raderer et al. 1999], gastrazole [Chau et al. 2006], goserilin [Philip et al. 1993], and tamoxifen [Bakkevold et al. 1990]. Ralitrexed achieved no response in one trial [Pazdur et al. 1996] and a low response in another [Francois et al. 2005]. Limited single-agent response was achieved using curcumin [Dhillon et al. 2006]. A complete response was noted in a randomized phase II trial of a semisynthetic version of an extract of the plant chelodium majus called NSC-631570 [Gansauge et al. 2002].

\section{Gemcitabine as a single agent}

Gemcitabine is currently the most active cytotoxic agent in metastatic PAC. The original phase II trials of gemcitabine achieved modest response rates of $11 \%$ [Casper et al. 1994] and 6\% [Carmichael et al. 1996], but the favourable 
toxicity profile enabled notable relief of cancer-related symptoms in responders. In one of these studies, $17 \%$ of patients noted improved performance status, 29\% experienced reduced pain, and 28\% described reduced nausea [Carmichael et al. 1996]. These observations provided the rationale for evaluation in a phase III trial (see Table 1).

Burris and colleagues compared single-agent gemcitabine to single-agent $5-\mathrm{FU}$ in a phase III study with the endpoints of median OS and clinical benefit [Burris et al. 1997]. Clinical benefit response occurred if the patient experienced an improvement in one of three areas - pain (either by analgesia use or on a rating scale), performance status, or weight - that lasted at least 4 weeks, and without deterioration in the remaining areas. One hundred and twenty-six patients were randomized to receive gemcitabine $\left(1000 \mathrm{mg} / \mathrm{m}^{2} \mathrm{q} 7 / 8 \mathrm{w}\right.$, then $\left.\mathrm{q} 3 / 4 \mathrm{w}\right)$ or $5-\mathrm{FU}$ $\left(600 \mathrm{mg} / \mathrm{m}^{2} \mathrm{q} 1 \mathrm{w}\right)$. Median OS was slightly but significantly longer in the gemcitabine group (5.7 months) than the 5-FU group (4.4 months), but more importantly gemcitabine achieved a higher clinical benefit response of $24 \%$, compared to $5 \%$ for $5-\mathrm{FU}$. Critics of the study point out that the control arm did not receive an optimal 5-FU regimen. However, on the basis of this small benefit - one quarter of patients receiving a month or more of symptomatic improvement - gemcitabine became the standard of care in metastatic PAC.

There is further randomized evidence that gemcitabine is more useful than an inactive agent (see Table 1). In a phase III trial of 277 patients, gemcitabine achieved better survival and quality of life than the matrix metalloproteinase inhibitor, BAY 12-9566 (Tanomastat) [Moore et al. 2003]. A retrospective review of 82 patients with advanced PAC also suggested that gemcitabine achieved greater clinical benefit (48\%) than 5-FU with folinic acid (19\%) [Klein et al. 2000].

\section{Gemcitabine regimen}

The gemcitabine regimen in the original phase II studies was $800 \mathrm{mg} / \mathrm{m}^{2} \mathrm{q} 3 / 4 \mathrm{w}$, but in later studies the dose was increased to 900 and then $1000 \mathrm{mg} / \mathrm{m}^{2}$ because of the low side-effect profile. The Burris regimen has been described above, but many institutions use an abridged $1000 \mathrm{mg} / \mathrm{m}^{2} \mathrm{q} 3 / 4 \mathrm{w}$ regimen. Three modified regimens bear some discussion - low-dose, dose-dense, and fixed-dose rate infusions.

A very small randomized trial $(n=25)$ found that low-dose gemcitabine delivered weekly $\left(250 \mathrm{mg} / \mathrm{m}^{2} \mathrm{q} 1 \mathrm{w}\right)$ achieved a similar median OS of 7.2 months when compared to standard gemcitabine, but with less haematologic toxicity in the low-dose group [Sakamoto et al. 2006]. This study is too small to draw any firm conclusions; however, it provides some support for a future trial examining the balance of toxicity and efficacy.

Dose-dense gemcitabine $\left(2200 \mathrm{mg} / \mathrm{m}^{2} \mathrm{q} 2 \mathrm{w}\right)$ has achieved similar results to standard gemcitabine in uncontrolled trials, with a response rate of $21 \%$ and a median OS of 8.8 months [Ulrich-Pur et al. 2000], and in a second trial at the same dose a median OS of 8.2 months [Scheithauer et al. 2003]. Nearly half of patients experienced effective palliation, and the regimen was well tolerated.

Fixed-dose rate (FDR) infusions have pharmacokinetic advantages in the laboratory, where they maximize the intracellular concentration of gemcitabine by avoiding saturation of the enzyme that

Table 1. Randomized controlled trials of single-agent gemcitabine compared to non-gemcitabine regimens in metastatic pancreatic adenocarcinoma.

\begin{tabular}{|c|c|c|c|c|c|c|c|c|}
\hline Author & $\begin{array}{l}\text { Sample } \\
\text { size }\end{array}$ & Interventions & $\begin{array}{l}\text { Radiological } \\
\text { response }\end{array}$ & $p$ value & $\begin{array}{l}\text { Clinical } \\
\text { benefit } \\
\text { response }\end{array}$ & $p$ value & $\begin{array}{l}\text { Median } \\
\text { overall } \\
\text { survival } \\
\text { (months) }\end{array}$ & $p$ value \\
\hline $\begin{array}{c}\text { Burris et al. } \\
1997\end{array}$ & 126 & $\begin{array}{l}\text { Gemcitabine } \\
\text { Weekly 5-FU }\end{array}$ & - & - & $\begin{array}{l}24 \% * \\
5 \%\end{array}$ & 0.002 & $5.7^{*} \quad 4.4$ & 0.003 \\
\hline $\begin{array}{l}\text { Moore et al. } \\
2003\end{array}$ & 277 & $\begin{array}{l}\text { Gemcitabine } \\
\text { BAY } 12-9566\end{array}$ & $\begin{array}{l}5 \% \\
<1 \%\end{array}$ & $\mathrm{np}$ & - & - & $6.6 * 3.7$ & $<0.001$ \\
\hline
\end{tabular}


Table 2. Randomized controlled trials of combined cytotoxic therapy in metastatic pancreatic adenocarcinoma.

\begin{tabular}{|c|c|c|c|c|c|c|c|c|}
\hline Author & Sample size & Interventions & $\begin{array}{l}\text { Radiological } \\
\text { response }\end{array}$ & $p$ value & $\begin{array}{l}\text { Clinical } \\
\text { benefit } \\
\text { response }\end{array}$ & $p$ value & $\begin{array}{l}\text { Median } \\
\text { overall } \\
\text { survival } \\
\text { (months) }\end{array}$ & $p$ value \\
\hline Colucci et al. 2002 & 107 & $\begin{array}{l}\text { Gem + Cis } \\
\text { Gem }\end{array}$ & $\begin{array}{l}26 \% * \\
9 \%\end{array}$ & 0.02 & $\begin{array}{l}53 \% \\
49 \%\end{array}$ & $\mathrm{np}$ & $\begin{array}{l}6.9 \\
4.6\end{array}$ & 0.43 \\
\hline Colucci et al. 2009 & 400 & $\begin{array}{l}\text { Gem + Cis } \\
\text { Gem }\end{array}$ & $\begin{array}{l}13 \% \\
10 \%\end{array}$ & 0.37 & $\begin{array}{l}15 \% \\
23 \%\end{array}$ & 0.057 & $\begin{array}{l}7.2 \\
8.3\end{array}$ & 0.38 \\
\hline Louvet et al. 2005 & 326 & $\begin{array}{l}\text { Gem + Oxa } \\
\text { Gem }\end{array}$ & $\begin{array}{l}27 \% * \\
17 \%\end{array}$ & 0.04 & $\begin{array}{l}38 \% * \\
27 \%\end{array}$ & 0.03 & $\begin{array}{l}9.0 \\
7.1\end{array}$ & 0.13 \\
\hline Heinemann et al. 2006 & 195 & $\begin{array}{l}\text { Gem + Cis } \\
\text { Gem }\end{array}$ & $\begin{array}{l}12 \% \\
9 \%\end{array}$ & $n p^{\$}$ & - & - & $\begin{array}{l}7.5 \\
6.0\end{array}$ & 0.15 \\
\hline Poplin et al. 2009 & 832 & $\begin{array}{l}\text { Gem + Oxa } \\
\text { FDR Gem } \\
\text { Gem }\end{array}$ & $\begin{array}{l}21 \% \\
21 \% \\
16 \%\end{array}$ & 0.11 & - & - & $\begin{array}{l}5.7 \\
6.2 \\
4.7\end{array}$ & 0.15 \\
\hline Hermann et al. 2007 & 319 & $\begin{array}{l}\text { Gem + Cap } \\
\text { Gem }\end{array}$ & $\begin{array}{l}10 \% \\
8 \%\end{array}$ & $\mathrm{np}$ & - & - & $\begin{array}{l}8.4 \\
7.2\end{array}$ & 0.23 \\
\hline Bernhard et al. 2008 & 319 & $\begin{array}{l}\text { Gem + Cap } \\
\text { Gem }\end{array}$ & - & - & $\begin{array}{l}19 \% \\
20 \%\end{array}$ & $\mathrm{np}$ & - & - \\
\hline $\begin{array}{l}\text { Scheithauer et al. } \\
2003\end{array}$ & 83 & $\begin{array}{l}\text { Gem + Cap } \\
\text { Gem }\end{array}$ & $\begin{array}{l}17 \% \\
14 \%\end{array}$ & $\mathrm{np}$ & $\begin{array}{l}33 \% \\
48 \%\end{array}$ & $\mathrm{np}$ & $\begin{array}{l}8.2 \\
9.5\end{array}$ & $\mathrm{np}$ \\
\hline Riess et al. 2005 & 473 & $\begin{array}{l}\text { Gem + 5-FU } \\
\text { Gem }\end{array}$ & - & - & - & - & $\begin{array}{l}5.9 \\
6.2\end{array}$ & 0.68 \\
\hline Ducreux et al. 2002 & 207 & $\begin{array}{l}5-F U+C i s \\
5-F U\end{array}$ & $\begin{array}{l}12 \% * \\
0 \%\end{array}$ & $<0.01$ & - & - & $\begin{array}{l}3.7 \\
3.4\end{array}$ & 0.10 \\
\hline Reni et al. 2005 & 99 & $\begin{array}{l}\text { Gem + Cis + } \\
5-F U+\text { Epi } \\
\text { Gem }\end{array}$ & $\begin{array}{l}39 \% * \\
9 \%\end{array}$ & 0.0008 & - & - & $\begin{array}{l}12 \% 2 \text { year* } \\
2 \% 2 \text { year }\end{array}$ & 0.03 \\
\hline Ychou et al. 2007 & 88 & $\begin{array}{l}\text { FOLFIRINOX } \\
\text { Gem }\end{array}$ & $\begin{array}{l}41 \% \\
12 \%\end{array}$ & $\mathrm{np}$ & - & - & - & - \\
\hline
\end{tabular}

transforms the drug into the active metabolites. FDR appeared promising in retrospective and phase II work [Cessot et al. 2009]. Indeed, a randomized phase II study of 92 patients showed that patients who received FDR gemcitabine $\left(1500 \mathrm{mg} / \mathrm{m}^{2}\right.$ over $\left.150 \mathrm{~min} \mathrm{q} 3 / 4 \mathrm{w}\right)$ had higher 1 year, 2 year and OS than patients who received high-dose gemcitabine $\left(2200 \mathrm{mg} / \mathrm{m}^{2} \mathrm{q} 3 / 4 \mathrm{w}\right.$ over $30 \mathrm{~min}$ ) [Tempero et al. 2003]. The cost for this benefit was increased haematological toxicity in the FDR group, and statistical significance was lost when only metastatic patients were included. Therefore, FDR gemcitabine $\left(1500 \mathrm{mg} / \mathrm{m}^{2}\right.$ over $150 \mathrm{~min} \mathrm{q} 3 / 4 \mathrm{w}$ ) was compared to standard gemcitabine (Burris regimen) in a multicentre RCT with over 800 patients [Poplin et al. 2009]. FDR gemcitabine acheived an improvement in 1-year survival from $16 \%$ to $21 \%$ (in pairwise comparison), but this did not meet the prespecified significance level. Median OS was not significantly different, and there was more myelosuppression in the FDR group. The authors concluded that
FDR gemcitabine did not offer substantial benefit.

\section{Gemcitabine in combination}

Gemcitabine as a single agent is only modestly effective but is relatively well tolerated. Gemcitabine in combination with other agents such as platinum drugs, fluoropyrimidines and taxanes have therefore been explored, but with mixed results (see Table 2).

\section{Platinum drugs}

Platinum agents have activity when added to gemcitabine, but have not produced a survival advantage in randomized trials. Fortnightly oxaliplatin $\left(100 \mathrm{mg} / \mathrm{m}^{2} \mathrm{~d} 2\right)$ and gemcitabine $\left(1000 \mathrm{mg} / \mathrm{m}^{2} \mathrm{~d} 1\right)$ improved response rate and 'clinical benefit' more than gemcitabine alone $\left(1000 \mathrm{mg} / \mathrm{m}^{2} \mathrm{q} 1 \mathrm{w}\right)$, but did not improve survival [Louvet et al. 2005]. Adding cisplatin $\left(25 \mathrm{mg} / \mathrm{m}^{2}\right.$ $\mathrm{q} 3 / 4 \mathrm{w})$ to gemcitabine (Burris regimen) improved response rate in a mixed group 
[Colucci et al. 2002], but the effect was not sustained in the phase III study that followed [Colucci et al. 2009] (see Table 2). In another randomized study, cisplatin and gemcitabine $\left(50 \mathrm{mg} / \mathrm{m}^{2}\right.$ and $1000 \mathrm{mg} / \mathrm{m}^{2}$, respectively, $\mathrm{q} 2 \mathrm{w}$ ) did not improve response rate or median OS compared to gemcitabine alone [Heinemann et al. 2006].

Several uncontrolled phase II trials support mild activity of gemcitabine-platinum schedules, with consistent response rates above $10 \%$ and median OS of more than 7 months [Ferrari et al. 2008; Lee et al. 2008a; Ueno et al. 2007a; Ko et al. 2006; Alberts et al. 2003]. A single-centre retrospective review of gemcitabine and oxaliplatin showed an objective response in $16 \%$ of patients, and a median OS of 9 months [Di Marco et al. 2007].

\section{Fluoropyrimidines}

The addition of an oral fluoropyrimidine to gemcitabine has not produced an improvement in response or survival in RCTs, despite initial positive phase II results. In phase II studies, capecitabine combined with standard gemcitabine [Park et al. 2006], FDR gemcitabine [Tonini et al. 2009], and intermediate-dose gemcitabine $\left(800 \mathrm{mg} / \mathrm{m}^{2} \mathrm{q} 2 / 3 \mathrm{w}\right)$ [Reza et al. 2007] achieved response rates above $20 \%$. But in a phase III study, the addition of capecitabine $\left(650 \mathrm{mg} / \mathrm{m}^{2}\right.$ bd $\mathrm{d} 1-14, \mathrm{q} 3 \mathrm{w})$ to gemcitabine $\left(1000 \mathrm{mg} / \mathrm{m}^{2}\right.$ $\mathrm{q} 2 / 3 \mathrm{w}$ ) did not improve survival [Bernhard et al. 2008], except in a posthoc analysis in patients with good performance status [Herrmann et al. 2007]. Similarly, adding capecitabine $\left(2500 \mathrm{mg} / \mathrm{m}^{2} \mathrm{~d} 1-7 \mathrm{q} 2 \mathrm{w}\right)$ to dose-dense gemcitabine $\left(2200 \mathrm{mg} / \mathrm{m}^{2} \mathrm{~d} 1 \mathrm{q} 2 \mathrm{w}\right)$ in a second randomized study gave a trend towards clinical benefit but did not increase any measures of survival [Scheithauer et al. 2003].

The oral 5-FU pro-drug, S1, combined with gemcitabine has achieved response rates above $40 \%$ in four phase II trials in Japanese patients [Lee et al. 2008b; Sudo et al. 2008; Ueno et al. 2007b; Nakamura et al. 2006], and $17 \%$ in a fifth trial [Ohkawa et al. 2007]. Phase III studies are underway.

The combination of intravenous 5-FU and gemcitabine has been examined in a phase III trial [Riess et al. 2005] where 473 patients were randomized to receive GFF (gemcitabine $1000 \mathrm{mg} / \mathrm{m}^{2}$ $\mathrm{q} 4 / 6 \mathrm{w}, \quad 5-\mathrm{FU} \quad 750 \mathrm{mg} / \mathrm{m}^{2}$ 24h-infusion plus folinic acid $200 \mathrm{mg} / \mathrm{m}^{2} \mathrm{q} 4 / 6 \mathrm{w}$ ) or single-agent gemcitabine (Burris regimen). There was no difference in any survival endpoint. This result occurred despite uncontrolled phase II trials supporting the addition of 5-FU to gemcitabine. Gemcitabine, 5-FU and folinic acid (GEMFUFOL) [Oztop et al. 2004], (FOLFUGEM2) [Andre et al. 2004], oxaliplatin, 5-FU and folinic acid (FOLFOX-6) with gemcitabine sequentially [Ghosn et al. 2009], sequential 5-FU and gemcitabine [Nakamori et al. 2009], weekly 5-FU and gemcitabine boluses [Gennatas et al. 2006] all achieved response rates of over $20 \%$ or median OS beyond 11 months. Gemcitabine and $5-\mathrm{FU}$ boluses administered $\mathrm{q} 3 / 4 \mathrm{w}$ were tested in two trials, one positive [Kurtz et al. 2000] and one negative [Berlin et al. 2000].

\section{Other doublet combinations with gemcitabine}

Perhaps the most promising drug now in phase III trials is nab-paclitaxel, a formulation where paclitaxel is bound to albumin nanoparticles. Early results from a phase I/II study recently reported in abstract described a $26 \%$ response rate including one complete response [Von Hoff et al. 2009]. Phase II trials also suggest activity when gemcitabine is combined in doublets with epirubicin [Neri et al. 2002; Scheithauer et al. 1999], docetaxel [Des Guetz et al. 2007], mitomycin [Tuinmann et al. 2008], etoposide [Lange et al. 2006], lipid-complexed paclitaxel (EndoTAG-1) [Löhr et al. 2008; 2009] and paclitaxel GPM [Podoltsev et al. 2008]. Agents with little activity in doublet combination with gemcitabine include exatecan [Abou-Alfa et al. 2006], irinotecan [Stathopoulos et al. 2006; Rocha Lima et al. 2004], celecoxib [Dragovich et al. 2008] and curcumin [Epelbaum et al. 2008].

\section{Doublet combinations without gemcitabine}

Combinations without gemcitabine have little activity, including 5-FU and irinotecan [Di Costanzo et al. 1996], 5-FU with 13-cis-retinoic acid [Michael et al. 2007], irinotecan and docetaxel [Burtness et al. 2008], and cisplatin and 5-FU (despite infusional dosing and folinic acid modulation) [Wagener et al. 2002; Huguier et al. 2001; Nose et al. 1999]. The addition of cisplatin $\left(100 \mathrm{mg} / \mathrm{m}^{2} \mathrm{~d} 1,2\right)$ to $5-\mathrm{FU}$ (infusional $1000 \mathrm{mg} / \mathrm{m}^{2} \mathrm{~d} 1-5$ ) increased response rate in one randomized trial with $12 \%$ response in patients receiving the doublet, compared to no responses from single agent 5-FU [Ducreux et al. 2002]. However, as when platinum agents are added to gemcitabine, there was no survival difference (see Table 2). 


\section{Multiagent cytotoxic combinations}

Multidrug combinations covering multiple targets in the tumour cell cycle have the potential for multiple or overlapping toxicities. This may be offset by the use of low and frequent dosing, and by the choice of agents. The trials in single agent and doublet chemotherapy provided the rationale for the inclusion of gemcitabine, platinum agents, fluoropyrimidines, taxanes and epirubicin in multiagent regimens.

A randomized multicentre phase III trial comparing PEFG (cisplatin $40 \mathrm{mg} / \mathrm{m}^{2} \mathrm{~d} 1$, epirubicin $40 \mathrm{mg} / \mathrm{m}^{2} \mathrm{~d} 1$, gemcitabine $600 \mathrm{mg} / \mathrm{m}^{2} \mathrm{~d} 1$ and 8 , 5 -FU $200 \mathrm{mg} / \mathrm{m}^{2} \mathrm{~d} 1-28$ by continuous infusion; $\mathrm{q} 4 \mathrm{w})$ versus gemcitabine alone (Burris regimen) showed an improved response rate and survival with the combined regimen [Reni et al. 2005]. The 99 patients were randomized to PEFG or gemcitabine. More patients in the PEFG group responded (see Table 2). Analysis of secondary endpoints showed that survival at 1 year was not significantly improved $(39 \%$ versus $21 \%$, $p=0.11$ ), but survival at 2 years was improved (12\% versus $2 \%, p=0.03)$ [Reni et al. 2005]. Data from the same trial suggested that the PEFG regimen more often provided improved quality of life than gemcitabine alone, despite an increased rate of grade 3 and 4 neutropenia (43\%) and thrombocytopenia (29\%) [Reni et al. 2006a].

Variations of PEFG have been described. A fortnightly variant of PEFG called 'dose-intense' PEFG (DI-PEFG, using the same 5-FU schedule but with cisplatin $30 \mathrm{mg} / \mathrm{m}^{2} \mathrm{~d} 1$ and 15 , epirubicin $30 \mathrm{mg} / \mathrm{m}^{2} \mathrm{~d} 1$ and 15 , gemcitabine $800 \mathrm{mg} / \mathrm{m}^{2}$ $\mathrm{d} 1$ and $15 ; \mathrm{q} 4 \mathrm{w}$ ) achieved comparable survival to standard PEFG with a 1-year survival rate of $46 \%$ [Reni et al. 2006b]. Although this was an uncontrolled phase II trial with inter-trial comparison to the original PEFG study the relative efficacy combined with the low rates of grade 3 and 4 neutropenia (9\%) and thrombocytopenia ( $1 \%)$ suggests this may be a useful schedule for further consideration. A subsequent study of another variation of PEFG suggests that substitution of capecitabine $\left(1250 \mathrm{mg} / \mathrm{m}^{2} /\right.$ day $\left.\mathrm{d} 1-28\right)$ for infusional $5-\mathrm{FU}$, and docetaxel $\left(25 \mathrm{mg} / \mathrm{m}^{2} \mathrm{~d} 1\right.$ and 15) for epirubicin were both feasible manoeuvres and worthy of further investigation [Cereda et al. 2009].

Further multidrug combinations have been explored in uncontrolled phase II studies. GTX (gemcitabine $750 \mathrm{mg} / \mathrm{m}^{2}$ over 75 minutes, $\mathrm{d} 4$ and 11 , docetaxel $30 \mathrm{mg} / \mathrm{m}^{2} \mathrm{~d} 4$ and 11 and capecitabine $750 \mathrm{mg} / \mathrm{m}^{2}$ bd $\mathrm{d} 1-14, \mathrm{q} 3 \mathrm{w}$ ) achieved a response rate of around $20 \%$ and median OS of 15 months [Fine et al. 2009]. The combination of gemcitabine, cisplatin and infusional 5-FU achieved survival median OS of 9.0 months [Novarino et al. 2004] and 10 months [Kim et al. 2009]. Gemcitabine, 5-FU and cisplatin (GFP) and gemcitabine, oxaliplatin and infusional 5-FU both achieved an OS of 7.5 months in a mixed group [Wagner et al. 2007]. A retrospective audit of gemcitabine, cisplatin, folinic acid then bolus and infusional 5-FU described a $16 \%$ response rate and median OS of 11.8 months [Araneo et al. 2003]. These multidrug combinations await randomized testing.

\section{Multidrug combinations without gemcitabine}

First-line multidrug combinations without gemcitabine have had mixed results, with any effect tending to be offset by significant toxicity. An interim analysis (presented as an abstract) of a randomized trial of FOLFIRINOX (oxaliplatin $85 \mathrm{mg} / \mathrm{m}^{2} \mathrm{~d} 1$, irinotecan $180 \mathrm{mg} / \mathrm{m}^{2} \mathrm{~d} 1$, leucovorin $400 \mathrm{mg} / \mathrm{m}^{2} \mathrm{~d} 1,5-\mathrm{FU} 400 \mathrm{mg} / \mathrm{m}^{2}$ bolus $\mathrm{d} 1$ and $2,400 \mathrm{mg} / \mathrm{m}^{2} 46 \mathrm{~h}$ continuous infusion $\mathrm{q} 2 \mathrm{w}$ ) showed a better response rate than gemcitabine ( $41 \%$ versus $12 \%$ ) [Ychou et al. 2007]. Survival data were not provided. Also, a very small phase II study of POLF (paclitaxel $60 \mathrm{mg} / \mathrm{m}^{2}$ $\mathrm{q} 1 \mathrm{w}$, oxaliplatin $50 \mathrm{mg} / \mathrm{m}^{2} \mathrm{q} 1 \mathrm{w}$, leucovorin $20 \mathrm{mg} / \mathrm{m}^{2} \quad \mathrm{q} 1 \mathrm{w}$ and $5-\mathrm{FU} \quad 425 \mathrm{mg} / \mathrm{m}^{2} \quad \mathrm{q} 1 \mathrm{w}$ ) achieved symptomatic improvement in seven of nine participants [Chue, 2007].

Combinations with limited effect include streptozocin, mitomycin and 5-FU [Kelsen et al. 1991; GITSG, 1986; Oster et al. 1986], doxorubicin, mitomycin and 5-FU [GITSG, 1986; Oster et al. 1986], cisplatin, ara-c and caffeine [Kelsen et al. 1991], 5-FU, doxorubicin and cisplatin [Cullinan et al. 1990], 5-FU, doxorubicin, mitomycin-C and streptozocin [Bukowski et al. 1993], etoposide, folinic acid, 5-FU, interferon $\alpha-2 b$ [MacDonald et al. 2000], etoposide, folinic acid, 5-FU, epirubicin [Maiello et al. 1998], and 5-FU, cyclophosphamide, vincristine, methotrexate and mitomycin [Cullinan et al. 1990].

\section{Targeted therapy}

All cancers acquire six hallmark abilities to function as invasive tumours, including self sufficiency of growth signalling, insensitivity to antigrowth signals, evasion of apoptosis, limitless 
Table 3. Randomized controlled trials of first line targeted therapy in metastatic pancreatic adenocarcinoma.

\begin{tabular}{|c|c|c|c|c|c|c|}
\hline Author & Sample size & Interventions & $\begin{array}{l}\text { Radiological } \\
\text { response }\end{array}$ & $p$ value & $\begin{array}{l}\text { Median overall } \\
\text { survival (months) }\end{array}$ & $p$ value \\
\hline Moore et al. 2007 & 569 & $\begin{array}{l}\text { Gem + Erl } \\
\text { Gem }\end{array}$ & $\begin{array}{l}9 \% \\
8 \%\end{array}$ & $\mathrm{np}$ & $\begin{array}{l}6.2^{*} \\
5.9\end{array}$ & 0.04 \\
\hline Philip et al. 2007 & 766 & $\begin{array}{l}\text { Gem + Cet } \\
\text { Gem }\end{array}$ & $\begin{array}{l}7 \% \\
7 \%\end{array}$ & $\mathrm{np}$ & $\begin{array}{l}6.5 \\
6.0\end{array}$ & 0.14 \\
\hline Burtness et al. 2008 & 87 & $\begin{array}{l}\text { Irino + Docet + Cet } \\
\text { Irino + Docet }\end{array}$ & $\begin{array}{l}7 \% \\
5 \%\end{array}$ & $\mathrm{np}$ & $\begin{array}{l}5.3 \\
6.5\end{array}$ & $\mathrm{np}$ \\
\hline Kindler et al. 2009a & 632 & $\begin{array}{l}\text { Gem }+ \text { Axi } \\
\text { Gem }\end{array}$ & $\begin{array}{l}- \\
-\end{array}$ & - & $\begin{array}{l}8.2 \\
7.4\end{array}$ & (HR 1.06) \\
\hline Vervenne et al. 2008 & 607 & $\begin{array}{l}\mathrm{Gem}+\mathrm{Erl} \\
\mathrm{Gem}+\mathrm{Erl}+\mathrm{Bev}\end{array}$ & $\begin{array}{l}8.6 \% \\
13.5 \%\end{array}$ & $\mathrm{np}$ & $\begin{array}{l}6.0 \\
7.1\end{array}$ & (HR 0.89) \\
\hline Kindler et al. 2008 & 139 & $\begin{array}{l}\text { Gem }+ \text { Bev }+ \text { Cet } \\
\text { Gem }+ \text { Bev }+ \text { Erl }\end{array}$ & $\begin{array}{l}23 \% \\
18 \%\end{array}$ & $\mathrm{np}$ & $\begin{array}{l}7.8 \\
7.2\end{array}$ & $\mathrm{np}$ \\
\hline Bramhall et al. 2002 & 239 & $\begin{array}{l}\text { Gem + Mar } \\
\text { Gem }\end{array}$ & $\begin{array}{l}11 \% \\
16 \%\end{array}$ & 0.07 & $\begin{array}{l}5.4 \\
5.4\end{array}$ & 0.95 \\
\hline Wright et al. 2006 & 434 & $\begin{array}{l}\text { Gem + Vir } \\
\text { Gem }\end{array}$ & - & - & $\begin{array}{l}6.3 \\
6.0\end{array}$ & $\mathrm{np}$ \\
\hline
\end{tabular}

reproduction, the ability to invade and metastasize, and to develop a blood supply [Hanahan et al. 2000]. Mutations, deletions, and amplifications of genes that encode proteins that regulate cellular pathways are known to be present in metastatic PAC [Jones et al. 2008]. For example, PAC tumour cells achieve self sufficiency in growth signalling by epidermal growth factor receptor (EGFR) overexpression and activating k-RAS mutations, become insensitive to antigrowth signals through permissive cyclin-D mutations, and facilitate angiogenesis by vascular endothelial growth factor (VEGF) overexpression. These and other factors should, in theory, provide multiple targets for molecular therapy. Unfortunately, as with cytotoxic agents, the targeted agents have seen limited success so far (see Table 3).

Preventing self sufficiency in growth signalling Small-molecule EGFR tyrosine kinase inhibitors (TKIs) are the only targeted agents to show a survival advantage in RCTs, and have become the standard of care in some jurisdictions that can fund them. The addition of the oral EGFR TKI erlotinib (100 or $150 \mathrm{mg} /$ day) to gemcitabine increases survival [Moore et al. 2007], but some argue not in a clinically significant way (see Table 3). Median OS increased from 5.9 to 6.2 months, an improvement of about 10 days, despite no difference in objective response rate. More patients in the combined arm developed an interstitial lung disease-like syndrome. There was more diarrhoea in the combined group, but no other difference in the quality-of-life measures.

Erlotinib has also shown activity with gemcitaibine in a small nonrandomized phase II study in a Japanese cohort, with a response rate of $20 \%$, although a quarter of patients discontinued the drug due to adverse effects [Nakachi et al. 2009]. Erlotinib with FDR gemcitabine achieved response rates of $24 \%$ [Espinosa et al. 2007] and $8 \%$ [Milella et al. 2009]. The efficacy of the EGFR TKI, gefitinib, compared to erlotinib may not be clear, however when coupled with gemcitabine it achieved a response rate of $7 \%$ and a median OS of 7.4 months [Fountzilas et al. 2007].

EGFR inhibitors have been combined with gemcitibine and a third agent in uncontrolled phase II trials. Erlotinib $(100 \mathrm{mg} /$ day $)$ added to gemcitabine $\left(1000 \mathrm{mg} / \mathrm{m}^{2} \mathrm{q} 3 / 4 \mathrm{w}\right)$ and capecitabine $\left(1660 \mathrm{mg} / \mathrm{m}^{2} /\right.$ day $\left.\mathrm{q} 3 / 4 \mathrm{w}\right)$ achieved a response rate of $32 \%$ and a median OS of 12 months [Oh et al. 2009], although EGFR overexpression was associated with a shorter response. Erlotinib with gemcitabine and docetaxel achieved a response rate of $22 \%$, improvement in pain or quality of life in $50 \%$, and a median OS of 5.3 months, although the regimen was reasonably toxic [Samelis et al. 2008]. Previous failure of regimens as they move from phase II to III trials suggests caution in interpreting these results. 
The anti-EGFR monoclonal antibodies have not been as effective as the TKIs (see Table 3). A phase III trial of gemcitabine plus cetuximab $\left(400 \mathrm{mg} / \mathrm{m}^{2} \mathrm{w} 1\right.$, then $\left.250 \mathrm{mg} / \mathrm{m}^{2} \mathrm{q} 1 \mathrm{w}\right)$ showed no improvement in median OS over gemcitabine alone (Burris regimen) [Philip et al. 2007]. Cetuximab did not improve response rate or median OS when added to irinotecan and docetaxel [Burtness et al. 2008]. These disappointing results in randomized trials occurred despite promising phase II results when cetuximab was added to a gemcitabine/oxaliplatin combination [Merchan et al. 2008; Kullmann et al. 2007], and from retrospective review of addition to oxaliplatin and irinotecan [Lee et al. 2007]. Perhaps the lack of response to EGFR monoclonals in PAC is not surprising given the k-RAS story in colorectal cancer. Cetuximab is not effective in colorectal cancer in the presence of an activating mutation in downstream k-RAS, presumably because inhibiting an upstream target no longer inhibits the EGFR pathway [Karapetis et al. 2008]. Unfortunately in PAC, an activating k-RAS mutation occurs in more than three-quarters of tumours [Pellegata et al. 1994].

Some hope for inhibiting pro-proliferation pathways remains. Talabostat, a small-molecule inhibitor of fibroblast activation protein achieved a complete response in one patient when coupled with gemcitabine a small phase II trial [Nugent et al. 2007]. The TGF-B2 inhibitor, AP12009, has achieved a complete response in a patient in a phase I/II trial [Oettle et al. 2007].

Inhibition of other targets in the EGFR pathway has been largely disappointing. As with cetuximab, the HER2 monolclonal receptor blocker, trastuzumab, has not been effective, even with tumours that overexpress HER2 on immunohistochemical (IHC) testing [Harder et al. 2009; Safran et al. 2004]. The latter study found that only $11 \%$ showed IHC3+ HER2 staining, suggesting that few PACs express an appropriate target for this agent. Perhaps not surprisingly then, lapatinib, a TKI that targets HER2, was also ineffective [Safran et al. 2009].

Other agents with little efficacy include the anti H-Ras agent, ISIS-2503 [Alberts et al. 2004], and the selective farnesyltransferase inhibitor, R115777, did not achieve significant response rates in combination with gemcitabine [Van Cutsem et al. 2004; Cohen et al. 2003]. Zoledronic acid is thought to inhibit p21 ras/
raf-1/MEK1/ERKL signalling but also showed little activity combined with gemcitabine [Cox et al. 2006].

\section{Inhibiting sustained angiogenesis}

A growing tumour must develop a blood supply to enable its growth. The VEGF inhibitor, bevacizumab, has only been tested as the sole targeted agent in addition to cytotoxic agents. All trials are uncontrolled and phase II, but response rates are promising. With fortnightly gemcitabine and docetaxel, bevacizumab $\left(10 \mathrm{mg} / \mathrm{m}^{2} \mathrm{q} 2 \mathrm{w}\right)$ achieved a response rate approaching $50 \%$ [Picozzi et al. 2009]. With gemcitabine and capecitabine, or with gemcitabine and cisplatin, bevacizumab $\left(15 \mathrm{mg} / \mathrm{m}^{2} \mathrm{q} 3 \mathrm{w}\right)$ achieved response rates over $20 \%$ and with median OS above 8 months [Iyer et al. 2008; Ko et al. 2007a]. With fortnightly gemcitabine and oxaliplatin, bevacizu$\mathrm{mab}(10 \mathrm{mg} / \mathrm{kg} \quad \mathrm{q} 2 \mathrm{w})$ showed a promising response rate of $39 \%$, but a high grade 3 and 4 toxicity rate of $86 \%$, mostly fatigue, nausea, pain and shortness of breath [Fogelman et al. 2009]. Similar results had been achieved in another phase II trial with the same protocol, but there were $4 \%$ treatment-related fatalities [Kim et al. 2007].

Other antiangiogenic agents have been trialled. The oral VEGF receptor (VEGFR) inhibitor, axitinib (5 $\mathrm{mg}$ bd ongoing), added to gemcitabine, gave a trend toward increase in OS in a randomized phase II trial [Spano et al. 2008], but the subsequent phase III trial was discontinued after an interim analysis showed no survival benefit [Kindler et al. 2009a] (see Table 3). The metalloproteinase inhibitor marimastat is also expected to have antiangiogenic properties, but did not have clinical efficacy in PAC [Bramhall et al. 2001, 2002]. The antiangiogenic monoclonal antibody, volocixumab, blocks fibronectin binding to a5 $\beta 1$ integrin and induces apoptosis of endothelial cells, and is being further evaluated after showing activity in early phase trials [Evans et al. 2007; Valle et al. 2006].

\section{Combined growth factor and angiogenesis inhibition}

Given the minimal reponse achieved from targeting a proliferative or an angiogenic pathway separately, researchers have attempted to block more than one pathway at a time. Reflecting this, the VEGF inhibitor, bevacizumab, has only moved through to randomized trials in combination with a second targeted agent (see Table 3). 
Adding bevacizumab to concurrent gemcitabine and erlotinib, saw a nonsignificant trend towards improved median OS in a phase III trial of 7.1 versus 6.0 months [Vervenne et al. 2008]. In this study, participants who did not develop a rash had a median OS of less than 5 months, whereas those who developed a grade 2 or higher rash achieved a median OS of more than 8 months [Van Cutsem et al. 2009].

Other studies of dual pathway inhibition have been only modestly effective. The addition of either cetuximab or erlotinib to gemcitabine and bevacizumab achieved a response rate of around $20 \%$ and a median OS of over 7 months [Kindler et al. 2008]. The combination of dual monoclonal antibodies cetuximab $\left(400 \mathrm{mg} / \mathrm{m}^{2}\right.$ initial dose then $250 \mathrm{mg} / \mathrm{m}^{2} \mathrm{q} 1 \mathrm{w}$ ) and bevacizumab $\left(10 \mathrm{mg} / \mathrm{m}^{2} \mathrm{q} 2 \mathrm{w}\right)$ without a cytotoxic agent showed no objective responses in a phase II trial, but a response rate of $10 \%$ when added to FDR gemcitabine [Ko et al. 2009]. It seems that a cytotoxic agent is still required as part of a successful regimen.

\section{Preventing evasion of apoptosis}

All cancers successfully evade cellular mechanisms of programmed cell death [Hanahan and Weinberg, 2000]. Some pro-apoptotic agents have shown promise in nonrandomized phase II trials. AMG655 (conatumumab) is a humanized monoclonal antibody that binds to human death receptor, and achieved a $23 \%$ response rate combined with gemcitabine [Kindler et al. 2009b]. Survival data are pending. The DNA pathway checkpoint activator, ARQ 501, probably activates a proapoptotic protein and has been associated with objective responses in a phase II trial [Khong et al. 2007]. A combination of gemcitabine, cisplatin and the supporter of apoptosis, $\mathrm{RP} 101$, achieved a response rate of $33 \%$ in a small phase II trial of 13 patients [Fahrig et al. 2006].

Some other pro-apoptotic agents have not appeared effective. Proteosome inhibitors might reduce the effect of $26 \mathrm{~S}$ proteasomes that break down proapoptotic proteins such as p53, but the proteasome inhibitor, bortezomib, has not been effective in PAC [Alberts et al. 2005]. The protein kinases of the AKT gene family are thought to promote survival of antiapoptotic genes, overcome cell cycle arrest, and have a role in tumour angiogenesis. The PKC $\beta$ and PI3K/AKT inhibitor, enzastaurin [Richards et al. 2009], and the
AKT inhibitor, perifosine [Marsh Rde et al. 2007], have not shown clinical utility.

\section{Reducing insensitivity to antigrowth signals}

Effective tumours must also become resistant to signals causing arrest of growth [Hanahan and Weinberg, 2000]. For example, histone deacetylase inhibitors might downregulate the $\mathrm{Rb}$ pathway in cell cycle control and downregulate p21 gene expression, thereby reducing inhibition of p53. Unfortunately, the oral histone deacetylase inhibitor, CI-994, was not effective [Richards et al. 2006].

\section{Targeting multiple pathways}

Tyrosine kinase inhibitors that target multiple pathways (multi-TKIs) are theoretically promising, but not yet tested beyond nonrandomized phase II trials. Masitinib ( $9 \mathrm{mg} / \mathrm{kg} /$ day), a multi-TKI targeting c-Kit, PDGFR, Fibroblast Growth Factor Receptor 3 and affecting the Focal Adhesion Kinase pathway, added to gemcitabine achieved a response rate of $23 \%$ in metastatic PAC and a median OS of 6.8 months [Mitry et al. 2009], and a clinical benefit rate of only $16 \%$ with a median OS of 7.1 months in another [Hammel et al. 2009]. The multi-TKI, sorafenib, targets b-Raf and VEGF among other targets, but had little impact in combination with gemcitabine [Wallace et al. 2007], or in combination with gemcitabine or erlotinib [Cohen et al. 2009].

\section{Other targets}

Triapine is a small molecule inhibitor of the DNA repair enzyme, ribonucleotide reductase, and had mild activity in PAC in one phase II trial [Greeno et al. 2006].

\section{Anticoagulation}

Patients with PAC experience high rates of venous thromboembolic disease (VTE). The low molecular weight heparins (LMWH) were initially thought to have inherent antitumour activity, but have more recently been trialled to reduce 'early death burden' from thrombosis. There is solid RCT evidence that prophylactic 'chemo-anticoagulation' in metastatic PAC reduces rate of VTE. In the CONKO 004 trial, the LMWH enoxaparin $(1 \mathrm{mg} / \mathrm{kg} /$ day $)$, reduced venous thromboembolic events from $15 \%$ to $5 \%$ without an increase in bleeding complications [Pelzer et al. 2009]. Similarly, the phase IIb UK-FRAGEM study compared gemcitabine with or without 100 days of weight adjusted dalteparin, with a significant reduction in VTE from 
$31 \%$ to $12 \%$ [Maraveyas et al. 2009]. Survival data for both trials are maturing, but interim analyses look unlikely to show an overall benefit. In contrast, the LMWH nadroparin, was not effective [Voorthuizen et al. 2006].

\section{Other modalities}

Modalities beyond cytotoxics and cell-pathway targeted agents have also been tested in metastatic PAC, including immune agents, gene therapy and hyperthermia.

Immune agents have not proved effective to date. The telemorase peptide vaccine, GV-1001, did not improve survival in combination with gemcitabine resulting in early stopping of this phase III trial [Buanes et al. 2009]. Virulizin is an intramuscular immune modulator that induces macrophage IL-12 production, which leads to Natural Killer cell-mediated antitumour activity. Virulizin combined with gemcitabine did not improve survival in a randomized phase III study [Wright et al. 2006]. Other immune agents in trial include the vaccine, panvac-VF G17DT, an immune stimulant that raises antibodies to growth factor gastrin-17 called immunogen, a vaccination therapy using degraded dendritic cells [Bauer et al. 2007], and a peptide vaccine matched to circulating IgG antibodies and cytotoxic T cells [Yanagimoto et al. 2006].

Gene therapy has been tested in a phase I/II trial, where intravenous rexin-G, a dominant negative analogue of the cyclin-G1 gene, was safe and achieved one partial response [Chawla et al. 2009].

Transdermal regional 'heating' of the tumour immediately after gemcitabine infusion has been reported to increase mean survival from 8 to 12 months in a multigroup phase II study, although this study was presented in abstract form, and it is not clear whether the groups were randomized [Yasuda et al. 2008]. The same process was applied to a small metastatic group $(n=12)$ in second-line treatment with a gemcitabine and cisplatin doublet, and although there were no radiological responses, 1-year survival was 30\% [Tschoep et al. 2006]. The value of localizing this heating in a disseminated disease awaits clarification.

\section{Second-line treatment}

An audit at a single centre showed that less than half of patients were given second-line chemotherapy [Schrag et al. 2007]. This may change after announcement of the first positive randomized phase III trial in second-line treatment of metastatic PAC.

\section{Second-line cytotoxic therapy}

The CONKO 003 investigators randomized 168 patients to receive $5-\mathrm{FU}$ and folinic acid with or without oxaliplatin (OFF, oxaliplatin $85 \mathrm{mg} / \mathrm{m}^{2}$ days 8,22 ; folinic acid $500 \mathrm{mg} / \mathrm{m}^{2}$ then 5 -FU $2600 \mathrm{mg} / \mathrm{m}^{2}$ days $1,8,15,22 \mathrm{q} 6 \mathrm{w}$ ) [Pelzer et al. 2008]. The group who received OFF had a significantly higher median OS of 6 months versus 3 months in the 5-FU group.

Oxaliplatin had shown mild activity in previous phase II studies before CONKO 003. The combination of 5-FU, folinic acid and oxaliplatin had resulted in one positive [Tsavaris et al. 2005] and one negative [Mitry et al. 2006] trial. Oxaliplatin had also been combined with 3-weekly ralitrexed and shown some improvement in quality of life [Reni et al. 2006c]. Capecitabine and oxaliplatin (Xelox) achieved a response in one of 15 patients in one study [Gasent Blesa et al. 2009] and one response in 39 patients in another [Xiong et al. 2006]. Patients randomized to FOLFOX (or FOLFIRI3) acheived combined partial response or stable disease of less than $30 \%$ [Hwang et al. 2009]. Pemitrexed and oxaliplatin achieved partial responses in three of 15 patients [Mazzer et al. 2009].

Phase II studies of other second-line cytotoxic agents have found a few with modest activity. S1 acheived response rates of $18 \%$ [Morizane et al. 2009] and 15\% [Sudo et al. 2008] in phase II trials, and $17 \%$ in a single-institution audit [Nakai et al. 2009]. Irinotecan monotherapy acheived $14 \%$ response rate [Boeck et al. 2007], and $16 \%$ in combination with ralitrexed [Ulrich-Pur et al. 2003]. Capecitabine and docetaxel achieved a $13 \%$ response rate in good performance status patients [Blaya et al. 2007], but no responses in a small trial in patients with poorer performance status [Lopes et al. 2006]. Ralitrexed alone achieved a $4 \%$ response rate [Boeck et al. 2006]. No objective responses were achieved by single-agent capecitabine $\left(1250 \mathrm{mg} / \mathrm{m}^{2}\right.$ bd d1-14 q3w), docetaxel and irinotecan [Ko et al. 2008], mitomycin, docetaxel and irinotecan [Reni et al. 2004], and mitomycin and ifosfamide [Cereda et al. 2008].

\section{Second-line targeted therapy}

Molecular targeted therapies have some activity in gemcitabine-refractory metastatic PAC, but are 
yet to be examined in randomized trials. Single-agent erlotinib achieved a $23 \%$ response rate in a heavily pretreated phase II mixed group [Epelbaum et al. 2007], and erlotinib titrated to induce rash achieved stable disease for longer than 8 weeks in one-quarter of 40 patients who had previously received gemcitabine [Tang et al. 2009]. A combined VEGF and PDGF inhibitor, valatinib, might have activity with $31 \%$ of patients alive at 6 months when given to a predominantly metastatic group [Dragovich et al. 2009].

Several single-agent, second-line targeted therapy trials have been negative. No second-line responses were achieved by the mammalian target of rapamycin inhibitor, everolimus [Shroff et al. 2009; Wolpin et al. 2008], the multi-TKI sunitinib [O'Reilly et al. 2008], the microtubule assembly inhibitors dolastatin-10 [Kindler et al. 2005] and ARC-100 [Reeves et al. 2009], the halichondrin B analogue eribulin [Moore et al. 2009], or the ribonucleotide reductase inhibitor, triapine [Groteluschen et al. 2006].

Several combinations of targeted agents and/or cytotoxic agents have also been ineffective to date in second-line treatment. This includes erlotinib and bevacizumab [Ko et al. 2007b], docetaxel and gefitinib [Shadad et al. 2006], docetaxel and the cyclin-dependent-kinase inhibitor flavopiridol [Carvajal et al. 2008], gefitinib and docetaxel [Blaszkowsky et al. 2007; Brell et al. 2007], and bevacizumab with docetaxel [Astsaturov et al. 2007].

In general, good performance status is the most important predictor of response to second-line therapy, and this clinical observation is supported by a retrospective multivariate analysis of a variety of cytotoxic schedules [Mancuso et al. 2007]. Gemcitabine is effective as second-line treatment in the event that the first-line regimen that did not contain gemcitabine, with a clinical benefit in $27 \%$ of patients that lasted for a median of 3 months [Rothenberg et al. 1996].

\section{The future}

There are 747 active trials on the US government clinical trials registry in PAC alone, including 41 phase III trials involving patients with metastatic PAC. Registered phase III trials will test gemcitabine with a second cytotoxic (5-FU, capecitabine, cisplatin, oxaliplatin, mitomycin, pemetrexed) or targeted agent (erlotinib, ccetuximab, bevicuzumab). Most of these trials have had initial reports. Several novel agents are currently in phase III trial, including newer cytotoxics nab-paclitaxel, S1, rubitecan, exatecan, and irofulven. These trials offer hope for improved responses through enhanced delivery of current agents or new regimens.

\section{Improved delivery of current agents}

Small gains may be made by maximizing the effectiveness of current chemotherapeutic agents. With respect to gemcitabine, there may be better ways to deliver this drug other than bolus or FDR dosing, and these might be guided by patient biology. For example, retrospective analysis of the RTOG 9704 trial showed that levels of hENT1, the protein that transports gemcitabine into cells, were correlated with survival after gemcitabine chemotherapy [Farrell et al. 2009]. In another example, studies in mouse models suggest that drug delivery to the tumour is reduced by desmoplastic stroma that is produced by these tumours [Olive et al. 2009]. They used an inhibitor of the Hedgehog pathway to reduce tumour stroma, improve intratumoural chemotherapy concentration and tumour response. This approach awaits clinical trial. Finally, multidrug regimens might provide further improvement in survival and clinical benefit.

\section{Personalized medicine}

Perhaps the greatest hope in the treatment of metastatic PAC lies with rational use of molecular targeted agents (or cytotoxics) in tumours where they are likely to be effective. This is no small feat in PAC, where analysis of the genome of 24 pancreatic tumours suggested an average of 63 mutations in PAC grouped into 12 key pathways [Jones et al. 2008]. The authors suggest that irrespective of the individual mutations, we might achieve more by targeting a point in each pathway downstream from the potential raft of mutation sites.

Rational use of therapies requires biomarkers that predict a subsequent response, and these are so far uncommon in pancreatic cancer. Pancreatic tumours known to overexpress SPARC (secreted protein acidic and rich in cysteine) have been more effectively targeted with nab-paclitaxel than tumours that do not express this protein [Von Hoff et al. 2009], and so might provide just such a marker. Some translational centres have trialled assessment of biomarkers of each individual tumour and attempted to predict a 
drug combination based on this profile. Trial results are pending.

It is also likely that epigenetic control of gene expression by methylation or noncoding RNA (eg microRNA) has a role in the pathogenesis of PAC, and therefore might be suitable for biomarkers.

\section{Improvements in trial design}

Trials in metastatic pancreatic cancer have been hampered by the short natural history of the disease, difficulty recruiting patients with a tissue diagnosis and appropriate performance status, and a relatively inactive standard of care. Trials are therefore small and recruitment slow, and researchers sometimes introduce further variance by including patients with unresectable but nonmetastatic disease. These patients typically have a longer survival, so including these patients in metastatic PAC trials adds noise to the data, making detection of a statistically signicant difference between groups more difficult.

Palliation is an important consideration when drugs have a limited impact on the natural history of PAC. Researchers use a variety of methods to measure quality of life from none, to clinical benefit surrogates, to formal inventories; but the lack of a sensitive tool makes detecting an improvement in quality of life difficult. Nonetheless, measurement of quality of life should be an expected part of all trials in metastatic PAC, as it is a key aim of treatment.

Finally, given that only one-quarter of patients will benefit from gemcitiabine, we need biomarkers to predict which $75 \%$ of patients should not receive chemotherapy unnecessarily. MicroRNA has shown predictive value in other tumour types, and candidate biomarkers should be included prospectively in all clinical trials in PAC. Recent examples in PAC include DPC4 gene status as a prognostic marker [Iacobuzio-Donahue et al. 2009], and certain mismatch repair gene polymorphisms as predictive markers [Dong et al. 2009]. Tumour tissue sample should also be collected from subjects in trials to also allow retrospective biomarker validation when new technologies arrive. It is difficult for many jurisdictions to offer established agents such as erlotinib due to cost, but the cost benefit improves markedly if we could predict which patients will respond.

\section{Acknowledgement}

Thanks to Anne Wilson of the Philson Library for assistance designing the search strategy.

\section{Conflict of interest statement}

None declared.

\section{References}

Abou-Alfa, G.K., Letourneau, R., Harker, G., Modiano, M., Hurwitz, H., Tchekmedyian, N.S. et al. (2006) Randomized phase III study of exatecan and gemcitabine compared with gemcitabine alone in untreated advanced pancreatic cancer. $\mathcal{F}$ Clin Oncol 24: $4441-4447$.

Alberts, S.R., Townley, P.M., Goldberg, R.M., Cha, S.S., Sargent, D.J., Moore, D.F. et al. (2003)

Gemcitabine and oxaliplatin for metastatic pancreatic adenocarcinoma: a North Central Cancer Treatment Group phase II study. Ann Oncol 14: 580-585.

Alberts, S.R., Schroeder, M., Erlichman, C., Steen, P.D., Foster, N.R., Moore, Jr D.F. et al. (2004) Gemcitabine and ISIS-2503 for patients with locally advanced or metastatic pancreatic adenocarcinoma: a North Central Cancer Treatment Group phase II trial. f Clin Oncol 22: 4944-4950.

Alberts, S.R., Foster, N.R., Morton, R.F., Kugler, J., Schaefer, P., Wiesenfeld, M. et al. (2005) PS-341 and gemcitabine in patients with metastatic pancreatic adenocarcinoma: a North Central Cancer Treatment Group (NCCTG) randomized phase II study. Ann Oncol 16: 1654-1661.

Andre, T., Noirclerc, M., Hammel, P., Meckenstock, R., Landi, B., Cattan, S. et al. (2004) Phase II study of leucovorin, 5-fluorouracil and gemcitabine for locally advanced and metastatic pancreatic cancer (FOLFUGEM2). Gastroenterol Clin Biol 28: 645-650.

Araneo, M., Bruckner, H.W., Grossbard, M.L., Frager, D., Homel, P., Marino, J. et al. (2003) Biweekly low-dose sequential gemcitabine, 5-fluorouracil, leucovorin, and cisplatin (GFP): a highly active novel therapy for metastatic adenocarcinoma of the exocrine pancreas. Cancer Invest 21: 489-496.

Ardalan, B. and Lima, M. (2004) A phase II trial of FUdr in patients with advanced pancreatic cancer. 7 Canc Res \& Clin Oncol 130: 561-566.

Asbury, R.F., Cnaan, A., Johnson, L., Harris, J., Zaentz, S.D. and Haller, D.G. (1994) An Eastern Cooperative Oncology Group phase II study of single agent DHAD, Vp-16, aclacinomycin, or spirogermanium in metastatic pancreatic cancer. Am f Clin Oncol 17: 166-169.

Astsaturov, I.A., Meropol, N.J., Alpaugh, R.K., Cheng, J.D., Lewis, N.L., Beard, M. et al. (2007) A randomized phase II and coagulation study of bevacizumab alone or with docetaxel in patients with previously treated metastatic pancreatic adenocarcinoma. F Clin Oncol 25(18S): Abstr 4556. 
Bakkevold, K.E., Pettersen, A., Arnesjo, B. and Espehaug, B. (1990) Tamoxifen therapy in unresectable adenocarcinoma of the pancreas and the papilla of vater. $\operatorname{Br} \mathcal{F} \operatorname{Surg} 77$ : 725-730.

Bauer, C., Dauer, M., Saraj, S., Schnurr, M., Jauch, K., Rüttinger, D. et al. (2007) Immunological and clinical response after vaccination therapy of pancreatic carcinoma patients with autologous, tumor-lysate pulsed dendritic cells: results of a phase II-study. f Clin Oncol 25(18S): Abstr 4579.

Berlin, J.D., Adak, S., Vaughn, D.J., Flinker, D., Blaszkowsky, L., Harris, J.E. et al. (2000) A phase II study of gemcitabine and 5-fluorouracil in metastatic pancreatic cancer: an Eastern Cooperative Oncology Group Study (E3296). Oncology 58: 215-218.

Bernhard, J., Dietrich, D., Scheithauer, W., Gerber, D., Bodoky, G., Ruhstaller, T. et al. (2008) Clinical benefit and quality of life in patients with advanced pancreatic cancer receiving gemcitabine plus capecitabine versus gemcitabine alone: a randomized multicenter phase III clinical trial-SAKK 44/00-CECOG/ Pan.1.3.001. f Clin Oncol 26: 3695-3701.

Blaszkowsky, L.S., Ryan, D.P., Earle, C., Kwak, E., Fuchs, C., Meyerhardt, J.A. et al. (2007) A phase II study of docetaxel in combination with ZD1839 (gefitinib) in previously treated patients with metastatic pancreatic cancer. F Clin Oncol 25(18S): Abstr 15080 .

Blaya, M., Lopes, G.L., Roman, E., Ahn, E., Macintyre, J., Quesada, J. et al. (2007) Phase II Trial of capecitabine and docetaxel as second line therapy for locally advanced and metastatic pancreatic cancer. f Clin Oncol 25(18S): Abstr 15029.

Boeck, S., Weigang-Koehler, K., Fuchs, M., Kettner, E., Quietzsch, D., Trojan, J. et al. (2006) Second-line therapy with pemetrexed after gemcitabine failure in patients with unresectable locally advanced or metastatic pancreatic cancer: a multicenter phase II trial. F Clin Oncol 24(18S): Abstr 4124.

Boeck, S., Wilkowski, R., Bruns, C.J., Issels, R.D., Schulz, C., Moosmann, N. et al. (2007) Oral capecitabine in gemcitabine-pretreated patients with advanced pancreatic cancer. Oncology 73: 221-227.

Bramhall, S.R., Rosemurgy, A., Brown, P.D., Bowry, C. and Buckels, J.A. Marimastat Pancreatic Cancer Study Group. (2001) Marimastat as first-line therapy for patients with unresectable pancreatic cancer: a randomized trial. f Clin Oncol 19: 3447-3455.

Bramhall, S.R., Schulz, J., Nemunaitis, J., Brown, P.D., Baillet, M. and Buckels, J.A. (2002) A

double-blind placebo-controlled, randomised study comparing gemcitabine and marimastat with gemcitabine and placebo as first line therapy in patients with advanced pancreatic cancer. Br f Cancer 87: 161-167.

Brell, J.M., Matin, K., Evans, T., Volkin, R.L., Keifer, G.J., Schlesselman, J.J. et al. (2007) Phase II study of gefitinib and docetaxel for patients with advanced pancreatic adenocarcinoma progressing after first-line therapy. Final Results. F Clin Oncol 25(18S): Abstr 4586.

Briasoulis, E., Pavlidis, N., Terret, C., Bauer, J., Fiedler, W., Schoffski, P. et al. (2003) Glufosfamide administered using a 1-hour infusion given as first-line treatment for advanced pancreatic cancer. A phase II trial of the EORTC-New Drug Development Group. Eur f Cancer 39: 2334-2340.

Buanes, T., Maurel, J., Liauw, W., Hebbar, M. and Nemunaitis, J. (2009) A randomized phase III study of gemcitabine versus GV1001 in sequential combination with $\mathrm{G}$ in patients with unresectable and metastatic pancreatic cancer. F Clin Oncol 27(15S): Abstr 4601.

Bukowski, R.M., Fleming, T.R., MacDonald, J.S., Oishi, N., Taylor, S.A. and Baker, L.H. (1993) Evaluation of combination chemotherapy and phase II agents in pancreatic adenocarcinoma. A Southwest Oncology Group Study. Cancer 71: 322-325.

Burch, P.A., Block, M., Schroeder, G., Kugler, J.W., Sargent, D.J., Braich, T.A. et al. (2000) Phase III evaluation of octreotide versus chemotherapy with 5-fluorouracil or 5-fluorouracil plus leucovorin in advanced exocrine pancreatic cancer: a North Central Cancer Treatment Group Study. Clin Cancer Res 6: 3486-3492.

Burris 3rd, H.A., Moore, M.J., Andersen, J., Green, M.R., Rothenberg, M.L., Modiano, M.R. et al. (1997) Improvements in survival and clinical benefit with gemcitabine as first-line therapy for patients with advanced pancreas cancer: a randomized trial. f Clin Oncol 15: 2403-2413.

Burtness, B.A., Powell, M.E., Berlin, J.D., Liles, D.K., Chapman, A.E., Mitchell, E.P. et al. (2008) Phase II ECOG trial of irinotecan/docetaxel with or without cetuximab in metastatic pancreatic cancer: updated survival and Ca19-9 results. F Clin Oncol 26: Abstr 4642 .

Carmichael, J., Fink, U., Russell, R.C., Spittle, M.F., Harris, A.L., Spiessi, G. et al. (1996) Phase II study of gemcitabine in patients with advanced pancreatic cancer. Br F Cancer 73: 101-105.

Cartwright, T.H., Cohn, A., Varkey, J.A., Chen, Y.M., Szatrowski, T.P., Cox, J.V. et al. (2002) Phase II study of oral capecitabine in patients with advanced or metastatic pancreatic cancer. $\mathcal{F}$ Clin Oncol 20: $160-164$.

Carvajal, R.D., Shah, M.A., Tse, A., Lefkowitz, R., Kelsen, D.P., Schwartz, G.K. et al. (2008) A phase II study of docetaxel followed by flavopiridol in advanced, gemcitabine-refractory pancreatic cancer. f Clin Oncol 26: Abstr 15558.

Casper, E.S., Green, M.R., Kelsen, D.P., Heelan, R.T., Brown, T.D., Flombaum, C.D. et al. (1994) Phase II trial of gemcitabine (2,2'-difluorodeoxycytidine) in patients with adenocarcinoma of the pancreas. Invest New Drugs 12: 29-34.

Cereda, S., Ghidini, M., Passoni, P., Rognone, A., Fugazza, C., Ceraulo, D. et al. (2008) Salvage therapy 
with mitomycin and ifosfamide in patients with gemcitabine-resistant metastatic pancreatic cancer. Ann Oncol 19(S9): Abstr G38.

Cereda, S., Rognone, A., Ghidini, M., Rezzonico, S., Passoni, P., Mazza, E. et al. (2009) A randomized phase II trial of two different four-drug combinations in advanced pancreatic adenocarcinoma: cisplatin, capecitabine, gemcitabine plus either epirubicin or docetaxel. Am Soc Clin Oncol, Gatro-into Symp 27(15S): Abstr 4614.

Cessot, A., Baudry, C., Chibaudel, B., Bourges, O., Bengrine-Lefevre, L., Afchain, P. et al. (2009) Modified gemcitabine fixed-dose rate as first-line chemotherapy in patients with advanced pancreatic cancer. Am Soc Clin Oncol, Gastro-int Symp: Abstr 201.

Chau, I., Cunningham, D., Russell, C., Norman, A.R., Kurzawinski, T., Harper, P. et al. (2006) Gastrazole (JB95008), a novel CCK2/gastrin receptor antagonist, in the treatment of advanced pancreatic cancer: results from two randomised controlled trials. Br F Cancer 94: 1107-1115.

Chawla, S.P., Chua, V.S., Beltran, K., Saralou, A., Gordon, E.M. and Hall, F.L. (2009) Phase I/II study of targeted gene delivery in vivo: effect of intravenous infusion of rexin-G on tumor growth and toxicity in chemotherapy-resistant metastatic pancreatic cancer. Am Soc Clin Oncol, Gastro-int Symp: Abstr 249.

Chue, B. (2007) Interim results of a weekly, metronomic dosing of paclitaxel, oxaliplatin, leucovorin, 5-FU (POLF) in the treatment of metastatic pancreatic cancer. $\mathcal{F}$ Clin Oncol 25(18S): Abstr 15175.

Cohen, S.J., Ho, L., Ranganathan, S., Abbruzzese, J.L., Alpaugh, R.K., Beard, M. et al. (2003) Phase II and pharmacodynamic study of the farnesyltransferase inhibitor R115777 as initial therapy in patients with metastatic pancreatic adenocarcinoma. $\mathcal{F}$ Clin Oncol 21: $1301-1306$.

Cohen, D.J., Ryan, T., Moskovits, T., Cazeau, N., Newman, E., Pachter, H.L. et al. (2009) Safety and tolerability of combined gemcitabine and erlotinib plus sorafenib in the first-line treatment of metastatic pancreatic cancer. F Clin Oncol 27: Abstr e15594.

Colucci, G., Giuliani, F., Gebbia, V., Biglietto, M., Rabitti, P., Uomo, G. et al. (2002) Gemcitabine alone or with cisplatin for the treatment of patients with locally advanced and/or metastatic pancreatic carcinoma: a prospective, randomized phase III study of the Gruppo Oncologia Dell'italia Meridionale. Cancer 94: 902-910.

Colucci, G., Labianca, R., Di Costanzo, F., Gebbia, V., Carteni, G., Massidda, B. et al. (2009) A randomized trial of gemcitabine versus $G$ plus cisplatin in chemotherapy-naive advanced pancreatic adenocarcinoma: the GIP-1 (Gruppo Italiano Pancreas- Goim/ Giscad/Goirc) Study. F Clin Oncol 27(15S): Abstr 4504 .

Cox, J.V., Cartwright, T., Neubauer, M., McCollum, D., Sandbach, J., Monticelli, M.A. et al. (2006) Phase II study of gemcitabine plus zoledronic acid in subjects with stage IV pancreatic cancer. $\mathcal{F}$ Clin Oncol 24(18S): Abstr 14002

Cullinan, S., Moertel, C.G., Wieand, H.S., Schutt, A.J., Krook, J.E., Foley, J.F. et al. (1990) A phase III trial on the therapy of advanced pancreatic carcinoma. Evaluations of the Mallinson regimen and combined 5-fluorouracil, doxorubicin, and cisplatin. Cancer 65: 2207-2212.

Des Guetz, G., Chauvenet, L., Paraiso, D., Mayeur, D., Aparicio, T., Chirat, E. et al. (2007) Docetaxel and gemcitabine in advanced pancreatic cancer patients: a multicentre study. F Clin Oncol 25(18S): Abstr 15065.

Dhillon, N., Wolff, R.A., Abbruzzese, J.L., Hong, D.S., Camacho, L.H., Li, L. et al. (2006) Phase II clinical trial of curcumin in patients with advanced pancreatic cancer. f Clin Oncol 24(18S): Abstr 14151.

Di Bartolomeo, M., Bajetta, E., Somma, L., Carnaghi, C., Bandieri, E., Del Vecchio, M. et al. (1996) Doxifluridine as palliative treatment in advanced gastric and pancreatic cancer patients. Oncology 53: $54-57$.

Di Costanzo, F., Tagliaventi, M., Carlini, P., Zironi, S., Mazzocchi, B., Bella, M. et al. (1996) High-dose folinic acid and fluorouracil with or without ifosfamide is an inactive combination in advanced pancreatic cancer. A randomized phase II study of the Italian Oncology Group for Clinical Research (G.O.I.R.C.). Am F Clin Oncol 19: 307-310.

Di Marco, M., Nobili, E., Di Cicilia, R., Brandi, G., Bertolini, S., Derenzini, E. et al. (2007) GemO as first-line chemotherapy in advanced pancreatic cancer: a monoinstitutional experience. F Clin Oncol 25(18S): Abstr 15179.

Dong, X., Jiao, L., Li, Y., Evans, D.B., Wang, H., Hess, K. et al. (2009) Significant associations of mismatch repair gene polymorphisms with clinical outcome of pancreatic cancer. F Clin Oncol 27: 1592-1599.

Dragovich, T., Burris 3rd, H., Loehrer, P., Von Hoff, D.D., Chow, S., Stratton, S. et al. (2008) Gemcitabine plus celecoxib in patients with advanced or metastatic pancreatic adenocarcinoma: results of a phase II trial. Am $\mathcal{F}$ Clin Oncol 31: 157-162.

Dragovich, T., Laheru, D.A., Crowley, J.J., Smith, L.S., Seng, J., Burris, H.A. et al. (2009) Phase II trial of vatalinib in patients with advanced or metastatic pancreatic adenocarcinoma who failed gemcitabine therapy. F Clin Oncol 26: Abstr 4615.

Ducreux, M., Rougier, P., Pignon, J.P., Douillard, J.Y., Seitz, J.F., Bugat, R. et al. (2002) A randomised trial comparing 5-FU with $5-\mathrm{FU}$ plus cisplatin in advanced pancreatic carcinoma. Ann Oncol 13: 1185-1191.

Epelbaum, R., Schnaider, J., Gluzman, A. and Figer, A. (2007) Erlotinib as a single-agent therapy in patients with advanced pancreatic cancer. Am Soc Clin Oncol, Gatro-int Symp: Abstr A202. 
Epelbaum, R., Vizel, B. and Bar-Sela, G. (2008) Phase II study of curcumin and gemcitabine in patients with advanced pancreatic cancer. $\mathcal{F}$ Clin Oncol 26: Abstr 15619.

Espinosa, E., Feliu, J., De Castro, J., Belda, C., Casado, E., Herrero, A. et al. (2007) Phase II study of a fixed dose-rate infusion of gemcitabine associated with erlotinib in advanced pancreatic carcinoma. f Clin Oncol 25(18S): Abstr 15013.

Evans, T., Ramanathan, R.K., Yazji, S., Glynne-Jones, R., Anthoney, A., Berlin, J. et al. (2007) Final results from cohort 1 of a phase II study of volociximab, an anti-A5 $\beta 1$ integrin antibody, in combination with gemcitabine in patients with metastatic pancreatic cancer. $\mathcal{F}$ Clin Oncol 25(18S):

Abstr 4549.

Fahrig, R., Quietzsch, D., Heinemann, V., Liebert, A. and Haenel, M. (2006) A phase II pilot trial with RP101 in advanced pancreatic carcinoma. $\mathcal{F}$ Clin Oncol 24(18S): Abstr 14000.

Farrell, J.J., Elsaleh, H., Garcia, M., Lai, R., Ammar, A., Regine, W.F. et al. (2009) Human equilibrative nucleoside transporter 1 levels predict response to gemcitabine in patients with pancreatic cancer. Gastroenterology 136: 187-195.

Ferrari, V.D., Grisanti, S., Valcamonico, F., Amoroso, V., De Ponti, S., Rangoni, G. et al. (2008) Bi-weekly fixed dose of gemcitabine plus 24 hours infusion of cisplatin in advanced/metastastic pancreatic cancer patients: a phase II study. $\mathcal{F}$ Clin Oncol 26: Abstr 15639.

Fine, R.L., Moorer, G., Sherman, W., Chu, K., Maurer, M., Chabot, J. et al. (2009) Phase II trial of GTX chemotherapy in metastatic pancreatic cancer. f Clin Oncol 27(15S): Abstr 4623.

Fogelman, D.R., Varadhachary, G., Xiong, H.Q., Chang, D.Z., Bullock, S.A., Ozer, H. et al. (2009) Final results of a bi-institution phase II study of gemcitabine, oxaliplatin, and bevacizumab for advanced pancreatic cancer. Am Soc Clin Oncol, Gatro-int Symp: Abstr A182.

Fountzilas, G., Murray, S., Xiros, N., Karayannopoulou, G., Dafni, U., Linardou, H. et al. (2007) Gemcitabine (G) combined with gefitinib in patients with inoperable or metastatic pancreatic cancer. A Phase II Trial. F Clin Oncol 25(18S): Abstr 15016.

Francois, E., Hebbar, M., Bennouna, J., Mayeur, D., Perrier, H., Dorval, E. et al. (2005) A phase II Trial of raltitrexed (Tomudex) in advanced pancreatic and biliary carcinoma. Oncology 68: 299-305.

Gansauge, F., Ramadani, M., Pressmar, J., Gansauge, S., Muehling, B., Stecker, K. et al. (2002) NSC-631570 (Ukrain) in the palliative treatment of pancreatic cancer. Results of a phase II trial. Langenbecks Arch Surg 386: 570-574.

Gasent Blesa, J., Alberola Candel, V., Giner Marco, V., Juan, O., Provencio Pulla, M., Llorca, C. et al. (2009) Phase II trial of second-line chemotherapy in metastatic pancreas cancer with the combination of oxaliplatin and capecitabine. $\mathcal{F}$ Clin Oncol 27: Abstr E15561.

Gebbia, N. and Gebbia, V. (1996) Single agent paclitaxel in the treatment of unresectable and/or metastatic pancreatic adenocarcinoma. Eur f Cancer 32A: $1822-1823$.

Gennatas, C., Michalaki, V., Mouratidou, D., Tsavaris, N., Andreadis, C., Photopoulos, A. et al. (2006) Gemcitabine combined with 5-fluorouracil for the treatment of advanced carcinoma of the pancreas. In Vivo 20: 301-305.

Ghosn, M., Farhat, F., Kattan, J., Saroufim, A., Nasr, F., Chahine, G. et al. (2009) Phase II study of sequential and modulated use of FOLFOX-6 followed by gemcitabine as the first-line treatment of locally advanced and/or metastatic pancreatic adenocarcinoma. Am Soc Clin Oncol, Gatro-int Symp: Abstr A196.

GITSG (Gastrointestinal Tumor Study Group) (1985) Phase II trials of maytansine, low-dose chlorozotocin, and high-dose chlorozotocin as single agents against advanced measurable adenocarcinoma of the pancreas. Cancer Treat Reports 69: 417-420.

GITSG (Gastrointestinal Tumor Study Group) (1986) Phase II studies of drug combinations in advanced pancreatic carcinoma: fluorouracil plus doxorubicin plus mitomycin $\mathrm{C}$ and two regimens of streptozotocin plus mitomycin c plus fluorouracil. f Clin Oncol 4: 1794-1798.

Greeno, E., Kindler, H.L., Peeters, M., Trowbridge, R.C., Chong, G., Valle, J.W. et al. (2006) A phase II study of triapine in combination with gemcitabine in patients with unresectable or metastatic pancreatic cancer. F Clin Oncol 24(18S): Abstr 4123.

Groteluschen, D.L., Mahoney, M.R., Pitot, H.C., Laheru, D., Kolesar, J., Thomas, J.P. et al. (2006) A multicenter phase 2 consortium (P2c) study of triapine in patients with advanced adenocarcinoma of the pancreas. F Clin Oncol 24(18S): Abstr 14118.

Hammel, P., Mornex, F., Deplanque, G., Mitry, E., Levy, P., Seitz, J. et al. (2009) Oral tyrosine kinase inhibitor masitinib in combination with gemcitabine with advanced pancreatic cancer: a multicenter phase II study. F Clin Oncol 27(15S): Abstr 4617.

Hanahan, D. and Weinberg, R.A. (2000) The hallmarks of cancer. Cell 100: 57-70.

Harder, J., Hofheinz, R., Möhler, M., Büchler, P., Klöppel, G., Bitzer, M. et al. (2009) Multicenter phase II trial of trastuzumab and capecitabine in patients with HER2 expressing metastasized pancreatic cancer. Eur f Cancer (Supp 7): Abstr 6597.

Heinemann, V., Quietzsch, D., Gieseler, F., Gonnermann, M., Schonekas, H., Rost, A. et al. (2006) Randomized phase III trial of gemcitabine plus cisplatin compared with gemcitabine alone in advanced pancreatic cancer. $\mathcal{F}$ Clin Oncol 24: 3946-3952. 
Herrmann, R., Bodoky, G., Ruhstaller, T., Glimelius, B., Bajetta, E., Schuller, J. et al. (2007) Gemcitabine plus capecitabine compared with gemcitabine alone in advanced pancreatic cancer: a randomized, multicenter, phase III trial of the Swiss Group for Clinical Cancer Research and the Central European Cooperative Oncology Group. $\mathcal{F}$ Clin Oncol 25: 2212-2217.

Huguier, M., Barrier, A., Valinas, R., Flahault, A., Adloff, M., Pezet, D. et al. (2001) Randomized trial of 5-fluorouracil, leucovorin and cisplatin in advanced pancreatic cancer. Hepato-Gastroenterology 48: $875-878$.

Hwang, J.Y., Yoo, C., Kim, T., Lee, J., Park, D., Seo, D. et al. (2009) A randomized phase II study of FOLFOX or FOLFIRI.3 as second-line therapy in patients with advanced pancreatic cancer previously treated with gemcitabine-based chemotherapy. $\mathcal{F}$ Clin Oncol 27(15S): Abstr 4618.

Iacobuzio-Donahue, C., Fu, B., Yachida, S., Luo, M., Abe, H., Henderson, C. et al. (2009) DPC4 gene status of the primary carcinoma correlates with patterns of failure in patients with pancreatic cancer. f Clin Oncol 27: 1806-1813.

Iyer, R.V., Yu, J., Garrett, C.R., Litwin, A., Khushalani, N., Tarquini, M. et al. (2008) Multicenter phase II study of gemcitabine, capecitabine, and bevacizumab in patients with advanced pancreatic cancer: final analysis of clinical and quality of life endpoints. F Clin Oncol 26: Abstr 4616.

Johnson, C.D., Puntis, M., Davidson, N., Todd, S. and Bryce, R. (2001) Randomized, dose-finding phase III study of lithium gamolenate in patients with advanced pancreatic adenocarcinoma. Br $\mathcal{F}$ Surg 88: $662-668$.

Jones, S., Zhang, X., Williams Parsons, D., Cheng-Ho Lin, J., Leary, R., Angenendt, P. et al. (2008) Core signaling pathways in human pancreatic cancers revealed by global genomic analyses. Science 26(321): 1801-1806.

Karapetis, C.S., Khambata-Ford, S., Jonker, D.J., O'Callaghan, C.J. and Tu, D. (2008) K-ras mutations and benefit from cetuximab in advanced colorectal cancer. N Engl f Med 359: 1757-1765.

Kelsen, D., Hudis, C., Niedzwiecki, D., Dougherty, J., Casper, E., Botet, J. et al. (1991) A phase III comparison trial of streptozotocin, mitomycin, and 5-fluorouracil with cisplatin, cytosine arabinoside, and caffeine in patients with advanced pancreatic carcinoma. Cancer 68: 965-969.

Khong, H.T., Dreisbach, L., Kindler, H.L., Trent, D.F., Jeziorski, K.G., Bonderenko, I. et al. (2007) A phase 2 study of ARQ 501 in combination with gemcitabine in adult patients with treatment naïve, unresectable pancreatic adenocarcinoma. $f$ Clin Oncol 25(18S): Abstr 15017.

Kilton, L.J., Benson 3rd, A.B., Greenberg, A., Johnson, P., Shapiro, C., Blough, R. et al. (1992) Phase II trial of fludarabine phosphate for adenocarcinoma of the pancreas. An Illinois Cancer Center Study. Invest New Drugs 10: 201-204.

Kim, G.P., Oberg, A.L., Foster, N.R., Jaslowski, A., Flynn, P.J., Campbell, D. et al. (2007) Phase II trial of bevacizumab, gemcitabine, oxaliplatin in patients with metastatic pancreatic adenocarcinoma. $\mathcal{F}$ Clin Oncol 25(18S): Abstr 4553

Kim, S., Yuh, Y. and Lee, H. (2009) A phase II study of combination chemotherapy with gemcitabine, 5-fluorouracil, and cisplatin for advanced pancreatic cancer. Eur f Cancer (Supp 7): Abstr 6593.

Kindler, H.L., Tothy, P.K., Wolff, R., McCormack, R.A., Abbruzzese, J.L., Mani, S. et al. (2005) Phase II trials of dolastatin-10 in advanced pancreaticobiliary cancers. Invest New Drugs 23: 489-493.

Kindler, H.L., Gangadhar, T., Karrison, T., Hochster, H.S., Moore, M.J., Micetich, K. et al. (2008) Final analysis of a randomized phase II study of bevacizumab and gemcitabine plus cetuximab or erlotinib in patients with advanced pancreatic cancer. $\mathcal{F}$ Clin Oncol 26: Abstr 4502.

Kindler, H.L., Garbo, L.E., Stephenson, J., Wiezorek, J., Sabin, T., Hsu, M. et al. (2009b) Safety and efficacy of AMG 655 in combination with gemcitabine in patients with metastatic pancreatic cancer. Am Soc Clin Oncol, Gatro-int Symp: Abstr 192.

Kindler, H.L., Ioka, T., Richel, D.J., Bennouna, J., Létourneau, R., Okusaka, T. et al. (2009a) A double-blinded, placebo-controlled, randomized, phase III study of axitinib (AG-013736) plus gemcitabine vs. $\mathrm{G}$ plus placebo in advanced pancreatic cancer patients. Eur $\mathcal{F}$ Cancer 7 (Supp 2): Abstr 6502

Klein, B., Sadikov, E., Mishaeli, M., Levin, I. and Figer, A. (2000) Comparison of 5-FU and leucovorin to gemcitabine in the treatment of pancreatic cancer. Oncol Reports 7: 875-877.

Ko, A.H., Dito, E., Schillinger, B., Venook, A.P., Bergsland, E.K. and Tempero, M.A. (2006) Phase II study of fixed dose rate gemcitabine with cisplatin for metastatic adenocarcinoma of the pancreas. Am Soc Clin Oncol, Gastro-int Symp 24: 379-385.

Ko, A.H., Dito, E., Schillinger, B., Venook, A.P., Bergsland, E.K., Korn, W.M. et al. (2007a) A phase II study of bevacizumab and erlotinib in patients with gemcitabine refractory metastatic adenocarcinoma of the pancreas. Am Soc Clin Oncol, Gatro-int Symp: Abstr A187.

Ko, A.H., Dito, E., Schillinger, B., Venook, A.P., Bergsland, E.K., Wong, D. et al. (2007a) A phase II study of gemcitabine given at fixed-dose rate infusion, low-dose cisplatin, and bevacizumab for metastatic adenocarcinoma of the pancreas: update with completion of study accrual. $\mathcal{F}$ Clin Oncol 25(18S): Abstr 4548 .

Ko, A.H., Dito, E., Schillinger, B., Venook, A.P., Bergsland, E.K. and Tempero, M.A. (2008) Excess toxicity associated with docetaxel and irinotecan in 
patients with metastatic, gemcitabine-refractory pancreatic cancer: results of a phase II study. Cancer Investig 26: 47-52.

Ko, A.H., Dicke, K., Gurtler, J., Keaton, M., Lenz, H., Firstenberg, B. et al. (2009) Phase II, randomized, open-label study of cetuximab and bevacizumab alone or in combination with fixed-dose rate gemcitabine as first-line therapy for patients with metastatic adenocarcinoma of the pancreas. Am Soc Clin Oncol, Gatroint Symp: Abstr A183.

Kullmann, F., Hollerbach, S., Dollinger, M., Harder, J., Fuchs, M., Messmann, H. et al. (2007) Cetuximab plus gemcitabine/oxaliplatin (GEMOXCET) in 1st line metastatic pancreatic cancer. First Results from a Multicenter Phase II Study. Am Soc Clin Oncol, Gatroint Symp: Abstr A128.

Kurtz, J.E., Kohser, F., Negrier, S., Trillet-Lenoir, V., Walter, S., Limacher, J.M. et al. (2000) Gemcitabine and protracted 5-FU for advanced pancreatic cancer. A phase II study. Hepato-Gastroenterology 47: 1450-1453.

Lange, M.K., Campbell, A.D., O’Rourke, T.J., Yost, K.J., Luttenton, C.R., Truszkowski, K.J. et al. (2006) Phase II trial to evaluate gemcitabine and etoposide for locally advanced or metastatic pancreatic cancer. Am Soc Clin Oncol, Gatro-int Symp: Abstr A131.

Lee, F., Roach, M., Heywood, G., Parasher, G., Rasila, K. and Rabinowitz, I. (2007) Biweekly oxaliplatin, irinotecan, and cetuximab for metastatic pancreatic cancer. Am Soc Clin Oncol, Gatro-int Symp: Abstr A226.

Lee, G., Kim, H., Kang, M., Kim, T., Kim, H. and Kang, J. (2008b) Phase II trial of S-1 in combination with gemcitabine in chemo-naïve patients with locally advanced or metastatic pancreatic cancer. 7 Clin Oncol 26: Abstr 15577.

Lee, K., Kim, M., Kim, Y., Ryoo, B., Lim, H., Song, H. et al. (2008a) Gemcitabine and oxaliplatin combination as the first-line treatment in advanced pancreatic cancer: a multicenter phase II study. f Clin Oncol 26: Abstr 15618.

Löhr, M., Haas, S., Bechstein, W., Karrasch, M., Mescheder, A., Meyer, I. et al. (2008) First-line treatment of inoperable pancreatic adenocarcinoma with lipid complexed paclitaxel nanoparticles plus gemcitabine compared with gemcitabine monotherapy. A prospective RCT - phase II study. F Clin Oncol 26: Abstr 4618

Löhr, M., Haas, S., Bechstein, W., Bodoky, G., Maerten, A., Fischbach, W. et al. (2009) A phase II trial of cationic liposomal paclitaxel in combination with gemcitabine in patients with unresectable pancreatic cancer. Am Soc Clin Oncol, Gatro-int Symp: Abstr LBA120.

Lopes, G., Bastos, B., Ahn, E., Quesada, J., Allison, M., Flores, A. et al. (2006) A phase II trial of capecitabine and docetaxel in patients with previously treated pancreatic cancer. $\mathcal{F}$ Clin Oncol 24(18S):

Abstr 14111.
Louvet, C., Labianca, R., Hammel, P., Lledo, G., Zampino, M.G., Andre, T. et al. (2005) Gemcitabine in combination with oxaliplatin compared with gemcitabine alone in locally advanced or metastatic pancreatic cancer: results of a GERCOR and GISCAD phase III trial. F Clin Oncol 23: 3509-3516.

MacDonald, J.S., Jacobson, J.L., Modiano, M., Moore, D.F., Gandara, D.R., Schroder, L.E. et al. (2000) A phase II trial of etoposide, leucovorin, 5-FU, and interferon alpha $2 \mathrm{~b}+\mathrm{G}-\mathrm{CSF}$ for patients with pancreatic adenocarcinoma: a Southwest Oncology Group Study (SWOG 9413). Invest New Drugs 18: 269-273.

Maiello, E., Gebbia, V., Giuliani, F., Testa, A., Giotta, F., Gebbia, N. et al. (1998) A phase II trial of etoposide, folinic acid, fluorouracil and epirubicin in advanced pancreatic carcinoma. Clinica Terapeutica 149: 351-355.

Mancuso, A., Sacchetta, S., Saletti, P., Tronconi, C., Milesi, L., Garassino, M. et al. (2007) Clinical and molecular determinants of survival in pancreatic cancer patients treated with second line chemotherapy: results of an Italian/Swiss multicenter survey. $\mathcal{F}$ Clin Oncol 25(18S): Abstr 4622.

Maraveyas, A., Waters, J., Roy, R., Propper, D., Fyfe, D., Lofts, F. et al. (2009) Gemcitabine with or without prophylactic weight-adjusted dalteparin in patients with advanced or metastatic pancreatic cancer: a multicentre, randomised phase IIb trial (the UK FRAGEM Study). Eur F Cancer 7(Supp 2): Abstr 6503.

Marsh Rde, W., Rocha Lima, C.M., Levy, D.E., Mitchell, E.P., Rowland Jr, K.M. and Benson, 3rd A.B. (2007) A phase II Trial of perifosine in locally advanced, unresectable, or metastatic pancreatic adenocarcinoma. Am f Clin Oncol 30: 26-31.

Mazzer, M., Zanon, E., Foltran, L., De Pauli, F., Cardellino, G., Iaiza, E. et al. (2009) Second-line pemetrexed-oxaliplatin combination for advanced pancreatic adenocarcinoma. $\mathcal{F}$ Clin Oncol 27: Abstr e15597.

Mekan, S.F., Komrokji, R.S., Beg, M.S., Nahleh, Z.A. and Safa, M.M (2007) Treatment of unresectable or metastatic pancreatic cancer in the VA population: does it improve survival? $\mathcal{F}$ Clin Oncol 25(18S): Abstr 15121 .

Merchan, J.R., Venkatraman, A., Macintyre, J., Ciombor, K., Levi, J., Ribeiro, A. et al. (2008) A pilot study of gemcitabine, oxaliplatin, cetuximab for locally advanced or metastatic pancreatic cancer. $\mathcal{F}$ Clin Oncol 26: Abstr 15510.

Michael, A., Hill, M., Maraveyas, A., Dalgleish, A. and Lofts, F. (2007) 13-cis-retinoic acid in combination with gemcitabine in the treatment of locally advanced and metastatic pancreatic cancer-report of a pilot phase II study. Clin Oncol 19: 150-153.

Milella, M., Sperduti, I., Gelibter, A., Bria, E., Cianci, G., Moscetti, L. et al. (2009) Erlotinib Combined with Fixed Dose-Rate Gemcitabine as Firstline Treatment 
for Advanced Adenocarcinoma of the Pancreas: Preliminary Results from a Multicenter Phase II Study. Eur F Cancer 7(Supp 2): Abstr 6598.

Mitry, E., Ducreux, M., Ould-Kaci, M., Boige, V., Seitz, J.F., Bugat, R. et al. (2006) Oxaliplatin Combined with 5-FU in Second Line Treatment of Advanced Pancreatic Adenocarcinoma. Results of a Phase II Trial. Gastroenterol Clin Biol 30: 357-363.

Mitry, E., Hammel, P., Deplanque, G., Mornex, F., Levy, P., Seitz, J. et al. (2009) Oral Tyrosine Kinase Inhibitor Masitinib in Combination with Gemcitabine in Patients with Advanced Pancreatic Cancer: A Multicenter Phase II Study. Am Soc Clin Oncol, Gatroint Symp: Abstr A242.

Moore, M.J., Hamm, J., Dancey, J., Eisenberg, P.D., Dagenais, M., Fields, A. et al. (2003) Comparison of gemcitabine versus the matrix metalloproteinase inhibitor bay 12-9566 in patients with advanced or metastatic adenocarcinoma of the pancreas: a phase III trial of the National Cancer Institute of Canada Clinical Trials Group. f Clin Oncol 21: 3296-3302.

Moore, M.J., Goldstein, D., Hamm, J., Figer, A., Hecht, J.R., Gallinger, S. et al. (2007) Erlotinib plus gemcitabine compared with gemcitabine alone in patients with advanced pancreatic cancer: a phase III trial of the National Cancer Institute of Canada Clinical Trials Group. F Clin Oncol 25: 1960-1966.

Moore, M.J., Tang, P., Renouf, D., Major, P., Hedley, D., Paterson, V. et al. (2009) A phase II study of halichondrin B analog eribulin mesylate (E7389) as second-line therapy for patients with advanced pancreatic cancer. F Clin Oncol 27: abstr e15634.

Morizane, C., Okusaka, T., Furuse, J., Ishii, H., Ueno, H., Ikeda, M. et al. (2009) A phase II study of S-1 in gemcitabine-refractory metastatic pancreatic cancer. Cancer Chemother Pharmacol 63: 313-319.

Nakachi, K., Okusaka, T.O., Funakoshi, A.F., Ioka, T.I., Yamao, K.Y., Ohkawa, S.O. et al. (2009) A phase II study of erlotinib plus gemcitabine in Japanese patients with unresectable pancreatic cancer. Eur $\mathcal{F}$ Cancer 7(Supp 2): Abstr 6590.

Nakai, Y., Isayama, H., Sasaki, T., Sasahira, N., Hirano, K., Tsujino, T. et al. (2009) The role of S-1 in gemcitabine-refractory pancreatic cancer: a retrospective single-institution study. F Clin Oncol 27: Abstr e15648.

Nakamori, S., Eguchi, H., Endo, W., Kashiwazaki, M., Sugimoto, K., Takeda, Y. et al. (2009) Multicenter phase II study of the combination of S-1 administration prior to gemcitabine for unresectable/recurrent pancreatic cancer. Am Soc Clin Oncol, Gastro-int Symp: Abstr A251.

Nakamura, K., Yamaguchi, T., Ishihara, T., Sudo, K., Kato, H. and Saisho, H. (2006) Phase II trial of oral S-1 combined with gemcitabine in metastatic pancreatic cancer. Br f Cancer 94: 1575-1579.

Negi, S.S., Agarwal, A. and Chaudhary, A. (2006) Flutamide in unresectable pancreatic adenocarcinoma: a randomized, double-blind, placebo-controlled trial. Invest New Drugs 24: 189-194.

Neri, B., Cini, G., Doni, L., Fulignati, C., Turrini, M., Pantalone, D. et al. (2002) Weekly gemcitabine plus epirubicin as effective chemotherapy for advanced pancreatic cancer: a multicenter phase II study. Br f Cancer 87: 497-501.

Nose, H., Okada, S., Okusaka, T., Furuse, J., Yoshino, M., Ogoshi, K. et al. (1999) 5-Fluorouracil continuous infusion combined with cisplatin for advanced pancreatic cancer: a Japanese cooperative study. Hepato-Gastroenterology 46: 3244-3248.

Novarino, A., Chiappino, I., Bertelli, G.F., Heouaine, A., Ritorto, G., Addeo, A. et al. (2004) Phase II study of cisplatin, gemcitabine and 5-fluorouracil in advanced pancreatic cancer. Ann Oncol 15: 474-477.

Nugent, F.W., Cunningham, C., Barve, M.A., Fisher, W., Patel, H., Meiri, E. et al. (2007) Phase 2 study of talabostat/gemcitabine in stage IV pancreatic cancer. f Clin Oncol 25(18S): Abstr 4616.

Oettle, H., Seufferlein, T., Schmid, R., Luger, T., Ludwig, S., Schmaus, S. et al. (2007) Preliminary results of a phase I/II study in pancreatic carcinoma, malignant melanoma, and colorectal carcinoma with the TGF- B2 inhibitor AP 12009. F Clin Oncol 25(18S): Abstr 4607.

Oh, D., Lee, K., Lee, K., Sohn, C., Park, Y., Zang, D. et al. (2009) A phase II trial of erlotinib in combination with gemcitabine and capecitabine in previously untreated metastatic/recurrent pancreatic cancer: combined analysis with translational research. f Clin Oncol 27(15S): Abstr 4607.

Ohkawa, S., Amano, A., Ueno, M., Miyakawa, K., Sugimori, K., Tanaka, K. et al. (2007) A phase II multicentric trial of combined chemotherapy with gemcitabine plus $S-1$ in patients with advanced pancreatic cancer. $\mathcal{F}$ Clin Oncol 25(18S):

Abstr 15129.

Olive, K., Jacobetz, M., Davidson, C., Gopinathan, A., Mcintyre, D., Honess, D. et al. (2009) Inhibition of Hedgehog signaling enhances delivery of chemotherapy in a mouse model of pancreatic cancer. Science 12(324): 1457-1461.

O'Reilly, E.M., Niedzwiecki, D., Hollis, D.R., BekaiiSaab, T.S., Pluard, T., Duffy, A. et al. (2008) A phase II trial of sunitinib in previously-treated pancreas adenocarcinoma, CALGB 80603. F Clin Oncol 26: Abstr 4515.

Oster, M.W., Gray, R., Panasci, L. and Perry, M.C. (1986) Chemotherapy for advanced pancreatic cancer. A comparison of 5-fluorouracil, adriamycin, and mitomycin (FAM) with 5-fluorouracil, streptozotocin, and mitomycin (FSM). Cancer 57: 29-33.

Oztop, I., Yilmaz, U., Yavuzsen, T., Yaren, A., Tarhan, O., Sagol, O. et al. (2004) Gemcitabine combined with infusional 5-fluorouracil and high-dose leucovorin for the treatment of advanced carcinoma of the pancreas. Chemotherapy 50: 127-132. 
Park, B., Park, J., Lee, H., Kim, H., Kwon, J., Oh, S. et al. (2006) A phase II trial of capecitabine plus gemcitabine for advanced pancreatic adenocarcinoma: analysis of clinical outcomes and CA19-9 response. Am Soc Clin Oncol, Gatro-int Symp: Abstr A114.

Pazdur, R., Meropol, N.J., Casper, E.S., Fuchs, C., Douglass, Jr. H.O., Vincent, M. et al. (1996) Phase II trial of ZD1694 (Tomudex) in patients with advanced pancreatic cancer. Invest New Drugs 13: 355-358.

Pellegata, N.S., Sessa, F., Renault, B., Bonato, M., Leone, B.E., Solcia, E. and Ranzani, G.N. (1994) K-ras and p53 gene mutations in pancreatic cancer: ductal and nonductal tumors progress through different genetic lesions. Cancer Res 54: 1556-1560.

Pelzer, U., Kubica, K., Stieler, J., Schwaner, I., Heil, G., Görner, M. et al. (2008) A randomized trial in patients with gemcitabine refractory pancreatic cancer. Final results of the CONKO 003 study. $\mathcal{F}$ Clin Oncol 26: Abstr 4508 (augmented by oral presentation).

Pelzer, U., Deutschinoff, G., Opitz, B., Stauch, M., Reitzig, P., Hahnfeld, S. et al. (2009) Successful prevention of symptomatic thromboembolic events by the low molecular weight heparin enoxaparin in patients with advanced pancreatic cancer - results of the CONKO 004 trial. Eur f Cancer 7(Supp 2): Abstr 6513.

Philip, P.A., Carmichael, J., Tonkin, K., Buamah, P.K., Britton, J., Dowsett, M. et al. (1993) hormonal treatment of pancreatic carcinoma: a phase II study of LHRH agonist goserelin plus hydrocortisone. Br f Cancer 67: 379-382.

Philip, P.A., Benedetti, J., Fenoglio-Preiser, C., Zalupski, M., Lenz, H., O'reilly, E. et al. (2007) Phase III study of gemcitabine plus cetuximab versus gemcitabine in patients with locally advanced or metastatic pancreatic adenocarcinoma: SWOG S0205 study. f Clin Oncol 25(18S): Abstr LBA4509.

Picozzi, V.J., Canlas, L.A., Sicuro, P.L. and Malpass, T.W. (2009) A phase II trial of gemcitabine, docetaxel, and bevacizumab (GDB) in metastatic pancreas cancer. F Clin Oncol 27(15S): Abstr 4606.

Podoltsev, N.A., Rubin, M.S., Figueroa, J.A., Lee, M.Y., Kwon, J., Yu, J. et al. (2008) Phase II clinical trial of paclitaxel loaded polymeric micelle in patients with advanced pancreatic cancer: final results. $f$ Clin Oncol 26: Abstr 4627.

Poplin, E., Feng, Y., Berlin, J., Rothenberg, M., Hochster, H., Mitchell, E. et al. (2009) Phase III, randomized study of gemcitabine and oxaliplatin versus gemcitabine (fixed-dose rate infusion) compared with gemcitabine (30-minute infusion) in patients with pancreatic carcinoma E6201: a trial of the Eastern Cooperative Oncology Group. $\mathcal{F}$ Clin Oncol 27: 3778-3785.

Raderer, M., Hamilton, G., Kurtaran, A., Valencak, J., Haberl, I., Hoffmann, O. et al. (1999) Treatment of advanced pancreatic cancer with the long-acting somatostatin analogue lanreotide: in vitro and in vivo results. Br f Cancer 79: 535-537.
Reeves, J., Infante, J.R., Bendell, J., Boccia, R., Dreisbach, L., Thomas, G. et al. (2009) Phase II study of ARC 100, a first in class microtubule inhibitor, in patients with advanced, unresectable pancreatic cancer after prior treatment with gemcitabine-based therapy. Am Soc Clin Oncol, Gatro-int Symp: Abstr A193.

Reni, M., Panucci, M.G., Passoni, P., Bonetto, E., Nicoletti, R., Ronzoni, M. et al. (2004) Salvage chemotherapy with mitomycin, docetaxel, and irinotecan (MDI regimen) in metastatic pancreatic adenocarcinoma: a phase I and II trial. Cancer Invest 22: $688-696$.

Reni, M., Cordio, S., Milandri, C., Passoni, P., Bonetto, E., Oliani, C. et al. (2005) Gemcitabine versus cisplatin, epirubicin, fluorouracil, and gemcitabine in advanced pancreatic cancer: a randomised controlled multicentre phase III trial. Lancet Oncol 6: 369-376.

Reni, M., Bonetto, E., Cordio, S., Passoni, P., Milandri, C., Cereda, S. et al. (2006a) Quality of life assessment in advanced pancreatic adenocarcinoma: results from a phase III randomized trial. Pancreatology 6: 454-463.

Reni, M., Cereda, S., Passoni, P., Bonetto, E., Viganò, M.G., Balzano, G. et al. (2006b) Phase IV trial of dose-intense PEFG (cisplatin, epirubicin, 5-fluorouracil, gemcitabine) in advanced pancreatic adenocarcinoma. f Clin Oncol 24(18S): Abstr 4121.

Reni, M., Pasetto, L., Aprile, G., Cordio, S., Bonetto, E., Dell'oro, S. et al. (2006c) Raltitrexed-eloxatin salvage chemotherapy in gemcitabine-resistant metastatic pancreatic cancer. Br f Cancer 94: 785-791.

Reza, M.S., Hai, M.A. and Chowdhury, Q. (2007) A phase II study of capecitabine-gemcitabine (CAPGEM) as a first line therapy in Bangladeshi patients with locally advanced or metastatic pancreatic adenocarcinoma. F Clin Oncol 25(18S): Abstr 15100.

Richards, D.A., Boehm, K.A., Waterhouse, D.M., Wagener, D.J., Krishnamurthi, S.S., Rosemurgy, A. et al. (2006) Gemcitabine plus CI-994 offers no advantage over gemcitabine alone in the treatment of patients with advanced pancreatic cancer: results of a phase II randomized, double-blind, placebo-controlled, multicenter study. Ann Oncol 17: 1096-1102.

Richards, D.A., Kuefler, P.R., Becerra, C., Wilfong, L.S., Gersh, R.H., Boehm, K.A. et al. (2009) Phase II randomized study of gemcitabine plus enzastaurin or single-agent gemcitabine in locally advanced or metastatic pancreatic cancer. Am Soc Clin Oncol, Gatro-int Symp: Abstr A189.

Riess, H., Helm, A., Niedergethmann, M., SchmidtWolf, I., Moik, M., Hammer, C. et al. (2005) A randomised, prospective, multicenter, phase III trial of gemcitabine, 5-fluorouracil (5-FU), folinic acid vs. gemcitabine alone in patients with advanced pancreatic cancer. 7 Clin Oncol 23(16S): Abstr 4009.

Rocha Lima, C.M., Green, M.R., Rotche, R., Miller, Jr. W.H., Jeffrey, G.M., Cisar, L.A. et al. (2004) 
Irinotecan plus gemcitabine results in no survival advantage compared with gemcitabine monotherapy in patients with locally advanced or metastatic pancreatic cancer despite increased tumor response rate. $f$ Clin Oncol 22: 3776-3783.

Rothenberg, M.L., Moore, M.J., Cripps, M.C., Andersen, J.S., Portenoy, R.K., Burris 3rd, H.A. et al. (1996) A phase II trial of gemcitabine in patients with 5-FU-refractory pancreas cancer. [See Comment]. Ann Oncol 7: 347-353.

Safran, H., Iannitti, D., Ramanathan, R., Schwartz, J.D., Steinhoff, M., Nauman, C. et al. (2004) Herceptin and gemcitabine for metastatic pancreatic cancers that overexpress HER-2/Neu. Cancer Invest 22: $706-712$.

Safran, H., Miner, T., Bahary, N., Whiting, S., Lopez, C., Sun, W. et al. (2009) Lapatinib and gemcitabine for metastatic pancreatic cancer: a phase II study. f Clin Oncol 27: Abstr e15653.

Sakamoto, H., Kitano, M., Suetomi, Y., Takeyama, Y., Ohyanagi, H., Nakai, T. et al. (2006) Comparison of standard-dose and low-dose gemcitabine regimens in pancreatic adenocarcinoma patients: a prospective randomized trial. $\mathcal{F}$ Gastroent 41: $70-76$.

Samelis, G.F., Tsiakou, A., Zaganides, A. and Ekmektzoglou, K. (2008) Survival benefit with erlotinib-based chemotherapy in unoperable recurrent and/or metastatic pancreatic cancer. F Clin Oncol 26: Abstr 15622.

Scheithauer, W., Kornek, G.V., Raderer, M., Hejna, M., Valencak, J., Miholic, J. et al. (1999) Phase II trial of gemcitabine, epirubicin and granulocyte colony-stimulating factor in patients with advanced pancreatic adenocarcinoma. $\mathrm{Br} \mathcal{F}$ Cancer 80: 1797-1802.

Scheithauer, W., Schull, B., Ulrich-Pur, H., Schmid, K., Raderer, M., Haider, K. et al. (2003) Biweekly high-dose gemcitabine alone or in combination with capecitabine in patients with metastatic pancreatic adenocarcinoma: a randomized phase II trial. Ann Oncol 14: 97-104.

Schrag, D., Archer, L., Wang, X., Romanus, D., Mulcahy, M., Goldberg, R. et al. (2007) A patterns-of-care study of post-progression treatment among patients with advanced pancreas cancer after gemcitabine therapy on Cancer and Leukemia Group B (CALGB) Study \#80303. F Clin Oncol 25(18S): Abstr 4524.

SEER Database (1996-2004) Survival Data Pancreas Cancer. Surveillance Epidemiological and End Results (SEER) Database National Cancer Institute: http:// seer.cancer.gov/

Shadad, F., Matin, K., Evans, T.L., Volkin, R.L., Kiefer, G.J., Schlesselman, J.J. et al. (2006) Phase II study of gefitinib and docetaxel as salvage therapy in patients with advanced pancreatic adenocarcinoma. f Clin Oncol 24(18S): Abstr 4120.
Shroff, R.T., Xiong, H.Q., Varadhachary, G.R., Kaseb, A., Fogelman, D.R., Ukegbu, L.T. et al. (2009) Inhibition of mammalian target of rapamycin (mTOR) in advanced pancreatic cancer: the results of two prospective phase II studies. Am Soc Clin Oncol, Gatroint Symp: Abstr A246.

Spano, J.P., Chodkiewicz, C., Maurel, J., Wong, R., Wasan, H., Barone, C. et al. (2008) Efficacy of gemcitabine plus axitinib compared with gemcitabine alone in patients with advanced pancreatic cancer: an open-label randomised phase II study. Lancet 371: 2101-2108.

Stathopoulos, G.P., Syrigos, K., Aravantinos, G., Polyzos, A., Papakotoulas, P., Fountzilas, G. et al. (2006) A multicenter phase III trial comparing irinotecan-gemcitabine with gemcitabine monotherapy as first-line treatment in patients with locally advanced or metastatic pancreatic cancer. $\mathrm{Br} \mathcal{F}$ Cancer 95: 587-592.

Stevenson, J.P., Scher, R.M., Kosierowski, R., Fox, S.C., Simmonds, M., Yao, K.S. et al. (1998) Phase II Trial of topotecan as a 21-day continuous infusion in patients with advanced or metastatic adenocarcinoma of the pancreas. Eur f Cancer 34: 1358-1362.

Strumberg, D., Bergmann, L., Graeven, U., Hanauske, A., Lipp, R., Schuette, J. et al. (2009) Results of a phase II trial of S-1 for first-line treatment of patients with metastatic pancreatic cancer (Cesar-Study Group). Am Soc Clin Oncol, Gatro-int Symp: Abstr 195.

Sudo, K., Yamaguchi, T., Nakamura, K., Hara, T., Ishihara, T. and Denda, T. (2008) S-1 in combination with gemcitabine for advanced pancreatic cancer. Ann Oncol 19(S8): Abstr 575.

Tang, P., Gill, S., Au, H.J., Chen, E.X., Hedley, D., Leroux, M. et al. (2009) Phase II trial of erlotinib in advanced pancreatic cancer. F Clin Oncol 27(15S): Abstr 4609.

Taylor, S.A., Fleming, T., Von Hoff, D.D., McCracken, J.D., Bukowski, R.M., Talley, R.W. et al. (1990) Phase II evaluation of mitoxantrone in advanced pancreatic carcinoma: a Southwest Oncology Group Study. Invest New Drugs 8: 77-80.

Tempero, M., Plunkett, W., Ruiz Van Haperen, V., Hainsworth, J., Hochster, H., Lenzi, R. et al. (2003) Randomized phase II comparison of dose-intense gemcitabine: thirty-minute infusion and fixed dose rate infusion in patients with pancreatic adenocarcinoma. f Clin Oncol 21: 3402-3408.

Tonini, G., Vincenzi, B., Vasile, E., Catalano, V., Virzì, V., Fontana, A. et al. (2009) Phase II capecitabine and gemcitabine fixed dose rate (FDR) in patients with advanced pancreatic cancer. Clin Oncol 27: Abstr e15530.

Tsavaris, N., Kosmas, C., Skopelitis, H., Gouveris, P., Kopterides, P., Loukeris, D. et al. (2005) Second-line treatment with oxaliplatin, leucovorin and 5 -fluorouracil in gemcitabine-pretreated advanced 
pancreatic cancer: a phase II study. Investigat New Drugs 23: 369-375.

Tschoep, K.E., Milani, V., Schmidt, G., Schiel, X., Abdel-Rahman, S., Kuhlencordt, M.F. et al. (2006) Gemcitabine + cisplatin in combination with regional hyperthermia in second-line therapy of gemcitabine-refractory metastatic pancreatic cancer. f Clin Oncol 24(18S): Abstr 14073.

Tuinmann, G., Mueller, L., Hossfeld, D. and Bokemeyer, C. (2008) A randomised phase II study of gemcitabine versus mitomycin $\mathrm{C}$ versus gemcitabine/ mitomycin $\mathrm{C}$ in patients with advanced pancreatic cancer. F Clin Oncol 26: Abstr 15658.

Ueno, H., Okada, S., Okusaka, T., Ikeda, M. and Kuriyama, H. (2002) Phase II study of uracil-tegafur in patients with metastatic pancreatic cancer. Oncology 62: 223-227.

Ueno, H., Okusaka, T., Ikeda, M., Takezako, Y. and Morizane, C. (2005) An early phase II study of S-1 in patients with metastatic pancreatic cancer. Oncology 68: $171-178$.

Ueno, H., Okusaka, T., Ikeda, M., Morizane, C., Ogura, T., Hagihara, A. et al. (2007a) Phase II study of combination chemotherapy with gemcitabine and cisplatin for patients with metastatic pancreatic cancer. fap f Clin Oncol 37: 515-520.

Ueno, H., Okusaka, T., Furuse, J., Yamao, K., Funakoshi, A., Boku, N. et al. (2007b) A multicenter phase II study of gemcitabine and S-1 combination therapy (GS therapy) in patients with metastatic pancreatic cancer. F Clin Oncol 25(18S): Abstr 4550.

Ulrich-Pur, H., Kornek, G.V., Raderer, M., Haider, K., Kwasny, W., Depisch, D. et al. (2000) A phase II trial of biweekly high dose gemcitabine for patients with metastatic pancreatic adenocarcinoma. Cancer 88: 2505-2511.

Ulrich-Pur, H., Raderer, M., Verena Kornek, G., Schull, B., Schmid, K., Haider, K. et al. (2003) Irinotecan plus raltitrexed vs raltitrexed alone in patients with gemcitabine-pretreated advanced pancreatic adenocarcinoma. $\mathrm{Br} \mathcal{F}$ Cancer 88: 1180-1184.

Valle, J.W., Ramanathan, R.K., Glynne-Jones, R., Anthoney, A., Berlin, J., Yazji, S. et al. (2006) Phase II study of volociximab (M200), an A5 $\beta 1$ anti-integrin antibody in metastatic adenocarcinoma of the pancreas. F Clin Oncol 24: Abstr 4111.

Van Cutsem, E., van de Velde, H., Karasek, P., Oettle, H., Vervenne, W.L. et al. (2004) Phase III trial of gemcitabine plus tipifarnib compared with gemcitabine plus placebo in advanced pancreatic cancer. f Clin Oncol 22: 1430-1438.

Van Cutsem, E., Vervenne, W.L., Bennouna, J., Humblet, Y. and Cosaert, J. (2009) Rash as a marker for the efficacy of gemcitabine plus erlotinib-based therapy in pancreatic cancer: results from the Avita Study. Am Soc Clin Oncol, Gatro-int Symp Abstr A117.
Van Rijswijk, R.E., Jeziorski, K., Wagener, D.J., Van Laethem, J.L., Reuse, S., Baron, B. et al. (2004) Weekly high-dose 5-fluorouracil and folinic acid in metastatic pancreatic carcinoma: a phase II study of the EORTC Gastrointestinal Tract Cancer

Cooperative Group. Eur F Cancer 40: 2077-2081.

Vervenne, W., Bennouna, J., Humblet, Y., Gill, S., Moore, M.J., Van Laethem, J. et al. (2008) A randomized, double-blind, placebo controlled, multicenter phase III trial to evaluate the efficacy and safety of adding bevacizumab to erlotinib and gemcitabine in patients with metastatic pancreatic cancer. F Clin Oncol 26: Abstr 4507.

Von Hoff, D.D., Ramanathan, R., Borad, M., Laheru, D., Smith, L., Wood, T. et al. (2009) SPARC correlation with response to gemcitabine plus nab-paclitaxel in patients with advanced metastatic pancreatic cancer: a phase I/II study. F Clin Oncol 27: Abstr 4525.

Voorthuizen, T.V., Vervenne, W.L., Van Daalen, E.H., Phoa, S.S., Gouma, D.J., Bruno, M.J. et al. (2006) A randomized phase II study comparing gemcitabine plus nadroparine versus gemcitabine in patients with locally advanced or metastatic pancreatic carcinoma: The GEMFRAX Trial. F Clin Oncol 24: Abstr 4112.

Wagener, D.J., Wils, J.A., Kok, T.C., Planting, A., Couvreur, M.L. and Baron, B. (2002) Results of a randomised phase II study of cisplatin plus 5-fluorouracil versus cisplatin plus 5-fluorouracil with alpha-interferon in metastatic pancreatic cancer: an EORTC Gastrointestinal Tract Cancer Group Trial. Eur $\mathcal{F}$ Cancer 38: 648-653.

Wagner, A.D., Buechner-Steudel, P., Wein, A., Schmalenberg, H., Lindig, U., Moehler, M. et al. (2007) Gemcitabine, oxaliplatin and weekly high-dose $5-\mathrm{FU}$ as $24-\mathrm{h}$ infusion in chemonaive patients with advanced or metastatic pancreatic adenocarcinoma: a multicenter phase II trial of the Arbeitsgemeinschaft Internistische Onkologie (AIO). Ann Oncol 18: 82-87.

Wallace, J.A., Locker, G., Nattam, S., Kasza, K., Wade-Oliver, K., Stadler, W.M. et al. (2007) Sorafenib Plus gemcitabine for advanced pancreatic cancer: a phase II trial of the University of Chicago Phase II Consortium. f Clin Oncol 25(18S): Abstr 4608.

Weinerman, B.H. and MaCcormick, R.E. (1994) A Phase II Survival Comparison of Patients with adenocarcinoma of the pancreas treated with 5-fluorouracil and calcium leucovorin versus a matched tumor registry control population. Am $\mathcal{F}$ Clin Oncol 17: 467-469.

Wils, J.A., Kok, T., Wagener, D.J., Selleslags, J. and Duez, N. (1993) Activity of cisplatin in adenocarcinoma of the pancreas. Eur f Cancer 29A: 203-204.

Wolpin, B.M., Hezel, A.F., Ryan, D.P., Abrams, T.A., Meyerhardt, J.A., Blaszkowsky, L.S. et al. (2008) Phase II study of RAD001 in previously treated patients with metastatic pancreatic cancer. $\mathcal{F}$ Clin Oncol 26: Abstr 4614.

Wright, J.A., Osterlee, J., Fekete, S., Lee, Y. and Young, A.H. (2006) A phase III trial of virulizin plus 
Visit SAGE journals online http://tam.sagepub.com

@SAGEJOURNALS Online gemcitabine vs. gemcitabine alone in advanced pancreatic cancer: results of subgroup analysis. f Clin Oncol 24: Abstr 4116.

Xinopoulos, D., Dimitroulopoulos, D., Karanikas, I., Fotopoulou, A., Oikonomou, N., Korkolis, D. et al. (2008) Gemcitabine as palliative treatment in patients with unresectable pancreatic cancer previously treated with placement of a covered metal stent. A randomized controlled trial. f BUON 13: 341-347.

Xiong, H.Q., Wolff, R.A., Hess, K.R., Varadhachary, G.R., Blais, J.C. and Abbruzzese, J.L. (2006) A phase II trial of oxaliplatin plus capecitabine (Xelox) as second line therapy for patients with advanced pancreatic cancer. F Clin Oncol 24(18S): Abstr 4119.

Yanagimoto, H., Mine, T., Yamamoto, K., Satoi, S., Honma, S., Mizoguchi, J. et al. (2006) Immunological evaluation of personalized peptide vaccination with gemcitabine for advanced pancreatic cancer patients. f Clin Oncol 24(18S): Abstr 14029.
Yasuda, M., Kondo, M., Kokura, S., Naito, Y., Norimasa, Y. and Yoshikawa, T. (2008) Comparison of concomitant gemcitabine chemotherapy and local hyperthermia, gemcitabine monochemotherapy, and local hyperthermia monotherapy for inoperable progressive pancreatic cancer. F Clin Oncol 26: Abstr 15672 .

Ychou, M., Desseigne, F., Guimbaud, R., Ducreux, M., Bouché, O., Bécouarn, Y. et al. (2007)

Randomized phase II trial comparing folfirinox (5FU/leucovorin, irinotecan and oxaliplatin) vs gemcitabine as first-line treatment for metastatic pancreatic adenocarcinoma. First results of the ACCORD 11 Trial. F Clin Oncol 25(18S): Abstr 4516.

Yip, D., Karapetis, C., Strickland, A., Steer, C. and Goldstein, D. (2006) Chemotherapy and radiotherapy for inoperable advanced pancreatic cancer. Cochrane Database of Systematic Reviews 2006 Jul 19; 3: CD002093. 